\title{
Development of Precipitated Iron Fischer-Tropsch Catalysts
}

Quarterly Technical Progress Report

for the Period 1 January 1996 - 31 March 1996

Texas Engineering Experiment Station Project 32525-44580

Prepared by: Dragomir B. Bukur

Contributors: $X$. Lang

Y. Ding

Texas A\&M University

Department of Chemical Engineering

College Station, Texas 77843-3122

June 3, 1996

Prepared for the Pittsburgh Energy Technology Center, the United States Department of Energy Under Contract No. DE-AC22-94PC93069

Richard E. Tischer, Project Manager (PETC)

"U.S. Department of Energy Patent Clearance not required prior to publication of this document" 


\section{NOTICE}

This report was prepared as an account of work sponsored by an agency of the United States Government. Neither the United States nor any agency thereof, nor any of their employees, makes any warranty, expressed or implied, or assumes any legal liability or responsibility of any third party's results of such use of any information, apparatus, product or process disclosed in this report,. or represents that its use by such a third party would not infringe privately owned rights.

\section{PATENT STATUS}

U. S. DOE Patent Clearance is not required prior to the publication of this document.

\section{TECHNICAL STATUS}

This technical report is being transmitted in advance of DOE review and no further dissemination or publication shall be made of the report without prior approval of the DOE Project/Program Manager. 


\section{DISCLAIMER}

Portions of this document may be illegible in electronic image products. Images are produced from the best available original document. 



\section{TABLE OF CONTENTS}

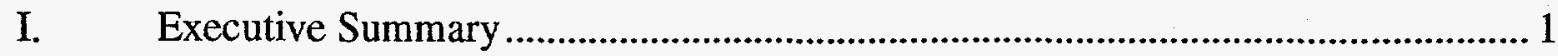

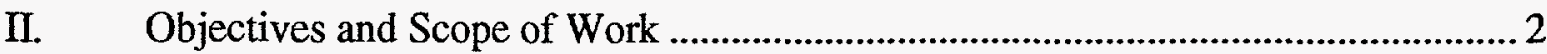

III. Detailed Description of Technical Progress …......................................................5

III. 1 Project Work Plan ................................................................................................. 5

III. 2 Engineering Modifications and Training of New Personnel .....................................5

III. 3. Testing of Previously Synthesized Catalysts ............................................................ 5

III. 4. Reproducibility of Catalyst Preparation ……............................................................. 5

III. 5. The Effect of Source of Potassium and Basic Oxide Promoter ...................................5

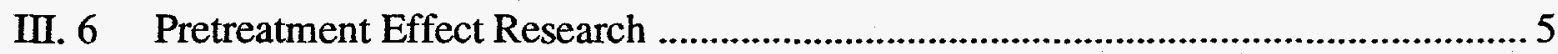

III. 7 Calcination Effect Research ................................................................................ 7

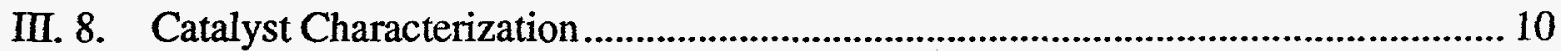

III. 9 Catalyst Testing in a Bubble Column Slurry Reactor................................................18

III. 10 Scale-up of Catalyst Synthesis Procedure..................................................................18

Plans for the Next Quarter

Tables.

Figures 


\section{EXECUTIVE SUMMARY}

A slurry reactor test (run SA-0376) was completed during the reporting period, following the catalyst pretreatment with $\mathrm{H}_{2}$ at $280^{\circ} \mathrm{C}$ for $8 \mathrm{~h}$ (Task 6. Pretreatment Effect Research). This pretreatment resulted in catalyst activity similar to the one obtained utilizing our baseline reduction procedure $\left(\mathrm{H}_{2}\right.$ at $240^{\circ} \mathrm{C}$ for $2 \mathrm{~h}$ ), and higher methane and gaseous hydrocarbon selectivities (about 10-20\% higher).

One fixed bed and one slurry reactor test were completed under Task 7 . Calcination Effect Research. For run FB-0236, the last of the four tests with catalyst B ( $100 \mathrm{Fe} / 5 \mathrm{Cu} / 6 \mathrm{~K} / 24$ $\mathrm{SiO}_{2}$ ) to study calcination effects in a fixed bed reactor, the catalyst was calcined at $700^{\circ} \mathrm{C}$ for 1 $h$ in a furnace (referred to as flash calcination). After the reduction with $\mathrm{H}_{2}$ at $250^{\circ} \mathrm{C}$ for $4 \mathrm{~h}$, the catalyst was tested at $250^{\circ} \mathrm{C}, 1.48 \mathrm{MPa}, 2.0 \mathrm{Nl} / \mathrm{g}$-cat/h, and synthesis gas feed with $\mathrm{H}_{2} / \mathrm{CO}=0.67$ for $120 \mathrm{~h}$. Catalyst activity was similar to the one obtained using our baseline calcination procedure $\left(300^{\circ} \mathrm{C}\right.$ for $\left.5 \mathrm{~h}\right)$, but gaseous hydrocarbon selectivities were slightly higher.

The effect of flash calcination was also studied in a slurry test SB-0676 using catalyst C $(100 \mathrm{Fe} / 3 \mathrm{Cu} / 4 \mathrm{~K} / 16 \mathrm{SiO} 2)$. The catalyst calcined at $700^{\circ} \mathrm{C}$ (SB-0676) had significantly lower activity than the catalyst calcined at $300^{\circ} \mathrm{C}$ (runs SB-2145 and SB-2145). Also, methane and gaseous hydrocarbon selectivities were higher on the catalyst calcined at $700^{\circ} \mathrm{C}$. However, they were stable with time, unlike those in runs SA-1665 and SB-2145 which increased with time and eventually led to similar values as those obtained in run SB-0676. This suggests that the catalyst calcined at high temperature has a more stable structure, which did not change during FT synthesis.

The work on catalyst characterization by temperature programmed and isothermal reduction was initiated on a variety of iron catalysts, with different amounts of promoters. These

studies are complementing our work on Task 6 , and provide additional insight into the effect of pretreatment procedures on the reduction behavior of iron catalysts. 


\section{OBJECTIVES AND SCOPE OF WORK}

The overall contract objectives are to: (1) demonstrate repeatability of performance and preparation procedure of two high activity, high alpha iron Fischer-Tropsch catalysts synthesized at Texas A\&M University (TAMU) during the DOE Contract DE-AC22-89PC89868; (2) seek potential improvements in the catalyst performance through variations in process conditions, pretreatment procedures and/or modifications in catalyst synthesis; (3) investigate performance of catalysts in a small scale bubble column slurry reactor, and (4) investigate feasibility of producing catalysts on a large scale in collaboration with a catalyst manufacturer. In order to achieve these objectives the work is divided into a number of tasks, which are described below together with the time schedule for their execution.

Task 1. Project Work Plan (April 1-April 30, 1994)

The objectives of this task are: (1) Prepare in detail all activities which shall be performed for the successful completion of the work for the entire duration of the contract; and (2) Provide a project work chart showing the key personnel/groups planned for each task, and the percentage of their time to be devoted to individual tasks.

Task 2. Engineering, Modification and Training of New Personnel (April 1-September 30, 1994)

The objective of this task is to perform the engineering design, procurement of new equipment, installation of the instruments and auxiliary gas supply lines and to provide training for new personnel prior to catalyst testing in laboratory reactors.

Task 3. Testing of Previously Synthesized Catalysts (October 1, 1994 - March 31, 1995)

The purpose of this task is to verify reproducibility of results obtained previously at TAMU with catalysts designated $\mathrm{B}\left(100 \mathrm{Fe} / 5 \mathrm{Cu} / 6 \mathrm{~K} / 24 \mathrm{SiO}_{2}\right)$ and $\mathrm{C}(100 \mathrm{Fe} / 3 \mathrm{Cu} / 4 \mathrm{~K} / 16$ $\mathrm{SiO}_{2}$ ). The catalysts from the same preparation batch shall be used, and the same pretreatment and process conditions shall be employed as in the previous slurry reactor tests of these two catalysts. 
Task 4. Reproducibility of Catalyst Preparation (October 1, 1994 - September 30, 1995)

The objective of this task is to demonstrate reproducibility of catalyst preparation procedure on a laboratory scale. Catalysts $\mathrm{B}$ and $\mathrm{C}$ will be synthesized following procedures developed at TAMU. Catalysts with satisfactory physico-chemical properties will be initially tested in a fixed bed reactor for screening purposes ( 5 day tests). Following this the two catalysts will be tested in a stirred tank slurry reactor (STSR) using standard pretreatment and process conditions. The activity, selectivity, deactivation behavior of these new catalyst batches will be compared to that of the catalysts from the original (existing) batches.

Task 5. The Effect of Source of Potassium and Basic Oxide Promoter (October 1, 1994 December 31, 1995)

The objective of this task is to determine effects of two different sources of potassium and addition of another promoter on the catalyst performance. Catalysts $B$ and $C$ will be synthesized using potassium silicate solution as the source of potassium promoter, and performance of these catalysts will be compared with that of catalysts synthesized using our standard procedure (i.e. using potassium bicarbonate as the source of potassium promoter).

The effect of $\mathrm{CaO}$ promotion on performance of catalysts $\mathrm{B}$ and $\mathrm{C}$ (two levels of promotion per catalyst) shall be investigated. Synthesized catalysts will be tested first in a fixed bed reactor, and if the satisfactory results are obtained the most promising catalyst formulations will be tested in the STSR.

\section{Task 6. Pretreatment Effect Research (October 1, 1995 - November 30, 1996)}

The effect of four different pretreatment procedures, in addition to the baseline procedure, on the performance of catalyst B (or C) will be studied in a STSR. In addition to STSR tests, the pretreatment effects will be studied by thermogravimetric analysis (TGA), differential thermal analysis (DTA) and temperature programmed reduction (TPR). Iron phases in the catalyst will be determined by X-ray powder diffraction (XRPD). 


\section{Task 7. Calcination Effect Research (October 1, 1995 - July 31, 1996)}

The effect of calcination temperature $\left(300-500^{\circ} \mathrm{C}\right)$ on the catalyst physical properties and performance during FT synthesis shall be studied in a fixed bed reactor and a STSR. In addition to the baseline calcination temperature of $300^{\circ} \mathrm{C}$, the calcination temperatures of 400 and $500^{\circ} \mathrm{C}$ will be employed in a fixed bed reactor with flowing air. Also, the effect of rapid heating (flash calcination) on performance of catalysts $B$ and $C$ shall be investigated.

\section{Task 8. Catalyst Characterization (December 1, 1994 - March 28, 1997)}

The objectives of this task are: (1) Provide basic characterization (by AA, BET, XRPD) of synthesized catalysts, and used catalysts (by XRPD, Mössbauer spectroscopy) in support of other tasks of the project; (2) Attempt to identify and quantify "surface" species on the catalyst after exposure to $\mathrm{CO}$ and/or synthesis gas by temperature programmed techniques (TPR/ TPD/ TPO/ TPRX) coupled with on-line gas analysis by mass spectrometry and gas chromatography.

Task 9. Catalyst Testing in a Bubble Column Slurry Reactor (October 1, 1996 - March 28, 1997)

A laboratory bubble column slurry reactor (BCSR) shall be designed, constructed and used for testing of catalysts B and C to quantify differences in the reactor space-time-yield and hydrocarbon selectivities between the STSR and the BCSR. This unit will be approximately 2.5 $\mathrm{cm}(\sim 1 \mathrm{in})$ in diameter and $1.5 \mathrm{~m}(\sim 5 \mathrm{ft})$ tall, with the effective (unexpanded or static) slurry volume of about $500 \mathrm{~cm}^{3}$.

Task 10. Scale-Up of a Catalyst Synthesis Procedure (April 1, 1996 - March 28, 1997)

By the end of the first eighteen months of this project, the repeatability of the catalyst performance and catalyst preparation procedure shall be demonstrated. Subsequently, if the performance of the catalysts is found satisfactory by DOE the Contractor shall work with a catalyst manufacturer on synthesis of a large batches $(-100 \mathrm{lb})$ of catalysts $B$ and C. The cost estimate for the catalyst preparation will be provided upon reviewing details of the preparation procedure, and submitted to DOE for approval. Upon the DOE approval the Contractor will test catalysts synthesized by a catalyst manufacturer in a STSR. 


\section{DETAILED DESCRIPTION OF TECHNICAL PROGRESS}

\section{1 Task 1. Project Work Plan}

The work on this task was completed. No additional activity to report.

III. 2

Task 2. Engineering Modifications and Training of New Personnel

The work on this task was completed. No additional activity to report.

III. 3

Task 3. Testing of Previously Synthesized Catalysts

The work on this task was completed. No additional activity to report.

\section{4 Task 4. Reproducibility of Catalyst Preparation}

The work on this task was completed. No additional activity to report.

III. 5

\section{Task 5. The Effect Of Source of Potassium and Basic Oxide Promoter}

The work on this task was completed. No additional activity to report.

III. 6

\section{Task 6. Pretreatment Effect Research}

Work on pretreatment effect research has continued in this quarter. A slurry reactor test (SA-0376) was completed with catalyst $\mathrm{C}\left(100 \mathrm{Fe} / 3 \mathrm{Cu} / 4 \mathrm{~K} / 16 \mathrm{SiO}_{2}\right)$, in which the catalyst was reduced with hydrogen at $280^{\circ} \mathrm{C}$ for $8 \mathrm{~h}$. The detailed description of the test results is given below, followed by comparison of results using three different hydrogen reduction procedures.

\section{6. 1 Run SA-0376 with $100 \mathrm{Fe} / 3 \mathrm{Cu} / 4 \mathrm{~K} / 16 \mathrm{SiO} 2$ Catalyst}

About $18 \mathrm{~g}$ of the catalyst ( $<270$ mesh in size) was loaded for the test, together with 300 g Durasyn 164 oil as the initial slurry medium. The pretreatment conditions applied were: $\mathrm{H}_{2}$ at $280^{\circ} \mathrm{C}, 0.78 \mathrm{MPa}(100 \mathrm{psig}), 950 \mathrm{~cm}^{3} / \mathrm{min}$ for $8 \mathrm{~h}$. In comparison with the standard reduction conditions for this catalyst $\left(240^{\circ} \mathrm{C}, 0.78 \mathrm{MPa}\right.$ for $\left.2 \mathrm{~h}\right)$, the higher reduction temperature $\left(280^{\circ} \mathrm{C}\right.$ vs. $240^{\circ} \mathrm{C}$ ) and longer reduction duration $(8 \mathrm{~h}$ vs. $2 \mathrm{~h}$ ) were employed, but the gas flowrate was significantly lower (950 vs. $\left.7,500 \mathrm{~cm}^{3} / \mathrm{min}\right)$. 
Following the reduction, the catalyst was first tested at $260^{\circ} \mathrm{C}, 1.48 \mathrm{MPa}$, syngas molar feed ratio of $0.67\left(\mathrm{H}_{2} / \mathrm{CO}=0.67\right)$ and gas space velocity of $1.4 \mathrm{~N} 1 / \mathrm{g}$-cat/h. As shown in Figure 1 , the $\mathrm{CO}$ conversion was about $83-80 \%,\left(\mathrm{H}_{2}+\mathrm{CO}\right)$ syngas conversion $77-76 \%$, and the $\mathrm{H}_{2} / \mathrm{CO}$ usage ratio was $0.56-0.57$ under these conditions. Methane selectivity after the reduction was low (2.8 mol\%), but it gradually increased to $4.0 \mathrm{~mol} \%$ at about $100 \mathrm{~h}$ and then leveled out (Figure 2a). Similarly, the $\mathrm{C}_{1}+\mathrm{C}_{2}$ selectivity increased from 5.8 to $8 \mathrm{~mol} \%$ (Figure $2 \mathrm{~b}$ ) and the $\mathrm{C}_{2}$ - $\mathrm{C}_{4}$ selectivity from $13 \mathrm{~mol} \%$ to $15 \mathrm{~mol} \%$ (Figure $2 \mathrm{c}$ ).

At $168 \mathrm{~h}$ on stream, the space velocity was increased to $2.3 \mathrm{Nl} / \mathrm{g}$-cat $/ \mathrm{h}$. This reduced $\mathrm{CO}$ and syngas conversions to 66 and $62 \%$, respectively, but did not result in change of the usage ratio. Selectivity to gaseous hydrocarbons continued to increase with time, reaching $4.3 \mathrm{~mol} \%$ for methane (Fig. 2a) and $16.5 \mathrm{~mol} \%$ for $\mathrm{C}_{2}-\mathrm{C}_{4}$ gaseous hydrocarbons (Fig. 2c).

At $254 \mathrm{~h}$, the reaction pressure was increased to $2.17 \mathrm{MPa}$ and space velocity to 2.05 $\mathrm{Nl} / \mathrm{g}$-cat/h, a proportional increase relative to the baseline conditions of $1.48 \mathrm{MPa}$ and $1.4 \mathrm{Nl} / \mathrm{g}$ cat $/ \mathrm{h}$ employed in the test. After $9 \mathrm{~h}$ at these conditions, the $\mathrm{CO}$ and the syngas conversions were 79 and $75 \%$, respectively. These values are similar to those measured at $167 \mathrm{~h}$ on stream (the last measurement at $1.48 \mathrm{MPa}$ and $1.4 \mathrm{~N} / \mathrm{g}$-cat/h), indicating no loss in catalyst activity between 167 and $256 \mathrm{~h}$ on stream. During the next $90 \mathrm{~h}$, the CO conversion decreased from 79 to $72 \%$, and the syngas conversion from 75 to $68 \%$. Gaseous hydrocarbon selectivities were not affected by catalyst deactivation during this period of time, and variations in data were mainly caused by fluctuations in the reactor temperature.

From 344 to $349 \mathrm{~h}$ on stream, a power outage occurred, causing slurry reactor temperature to cool down to $100^{\circ} \mathrm{C}$. The run was terminated at $350 \mathrm{~h}$ on stream after taking a slurry sample for catalyst characterization. Additional slurry samples were withdrawn during the test at : $0 \mathrm{~h}$ (after the reduction), $134 \mathrm{~h}$ and $230 \mathrm{~h}$ on stream, respectively. Table 1 summarizes major events for run SA-0376. 


\section{Pretreatment Effect Results - Comparison}

So far, three different pretreatment procedures have been studied with the $100 \mathrm{Fe} / 3 \mathrm{Cu} / 4$ $\mathrm{K} / 16 \mathrm{SiO}_{2}$ catalyst in slurry reactor tests. They are: (1) standard or baseline procedure with $\mathrm{H}_{2}$ at $240^{\circ} \mathrm{C}$ for $2 \mathrm{~h}$ (runs SA-1665 and SB-2145); (2) $\mathrm{H}_{2}$ at $250^{\circ} \mathrm{C}$ for $4 \mathrm{~h}$ (run SB-3425); and (3): $\mathrm{H}_{2}$ at $280^{\circ} \mathrm{C}$ for $8 \mathrm{~h}$ (run SA-0376). Comparison of the catalyst activities and selectivities in tests after different pretreatments are shown in Figures 3 and 4. The catalyst in run SA-0376 was reduced under the most severe conditions (the highest reduction temperature and the longest duration). Its activity, represented by the apparent rate constant (assuming the first order reaction in hydrogen partial pressure) in Figure 3, was similar to those observed in runs SA-1665 and SB2145 following the standard reduction procedure (the lowest reduction temperature and the shortest duration), but was markedly lower than the activity in run SB-3425. This demonstrates that the use of severe reduction conditions does not necessarily result in higher activity. Previous studies in our laboratory with iron based catalysts without silicon oxide, have shown that the use of more severe reduction conditions may result in very low catalyst activity. Methane and gaseous hydrocarbon selectivities in run SA-0376 were similar to those obtained in run SB-3425, and slightly higher than those in runs SA-1665 and SB-2145 (standard reduction procedure). This is consistent with results obtained previously in our laboratory, with other iron FischerTropsch catalysts, which showed that the use of more severe reduction conditions often results in higher gaseous selectivities. Reduced catalysts in runs SA-0376 and SB-3425 were in the form of magnetite and $\alpha-\mathrm{Fe}$, whereas the catalyst reduced at the standard conditions was in the form of magnetite (see section III. 8. 2 of the report and Figure 14).

\section{7 Task 7. Calcination Effect Research}

One fixed bed and one slurry reactor test were completed during the reporting period. For run FB-0236, the last of the four tests with catalyst $\mathrm{B}(100 \mathrm{Fe} / 5 \mathrm{Cu} / 6 \mathrm{~K} / 24 \mathrm{SiO} 2)$ to study calcination effects in a fixed bed reactor, the catalyst was calcined at $700^{\circ} \mathrm{C}$ for $1 \mathrm{~h}$ in a furnace (referred to as flash calcination, Quarterly Technical Progress Report for October-December, 
1995). After the reduction with $\mathrm{H}_{2}$ at $250^{\circ} \mathrm{C}$ for $4 \mathrm{~h}$, the catalyst was tested at $250^{\circ} \mathrm{C}, 1.48 \mathrm{MPa}$, $2.0 \mathrm{Nl} / \mathrm{g}$-cat $/ \mathrm{h}$, and synthesis gas feed with $\mathrm{H}_{2} / \mathrm{CO}=0.67$ for $120 \mathrm{~h}$. The effect of flash calcination was also studied in a slurry test SB-0676 using catalyst $\mathrm{C}(100 \mathrm{Fe} / 3 \mathrm{Cu} / 4 \mathrm{~K} / 16 \mathrm{SiO} 2)$.

\section{7.1 Fixed Bed Reactor Test of Catalyst B $(100 \mathrm{Fe} / 5 \mathrm{Cu} / 6 \mathrm{~K} / 24 \mathrm{SiO} 2)$}

Results illustrating catalyst activity and gaseous hydrocarbon selectivities in run FB0236 are shown in Figures 5 and 6, together with results from previous three tests using different calcination conditions (Quarterly Technical Progress Report for October-December, 1995). Some of the early decrease in the syngas conversion in run FB-0236 was due to fluctuations in bed temperature (Figures $5 \mathrm{a}$ and $5 \mathrm{~b}$ ). After $70 \mathrm{~h}$ on stream, the catalyst calcined at $700^{\circ} \mathrm{C}$ for 1 h, had similar $\mathrm{CO}$ and syngas conversions as those calcined at lower temperatures $\left(300\right.$ to $500^{\circ} \mathrm{C}$, for $5 \mathrm{~h}$ ). The usage ratio was similar $(0.58-0.60)$ in all four tests (Figure $5 \mathrm{c}$ ). On the other hand, the catalyst calcined at $700^{\circ} \mathrm{C}$ had higher methane and $\mathrm{C}_{2}-\mathrm{C}_{4}$ gaseous hydrocarbon selectivities (Figure 6), perhaps due to the presence of hot spots in the reactor. In general, the flash calcination or the use of higher calcination temperatures $\left(400\right.$ and $\left.500^{\circ} \mathrm{C}\right)$ did not result in improved catalyst performance (in terms of either activity or selectivity) in comparison to our baseline calcination procedure in air at $300^{\circ} \mathrm{C}$ for $5 \mathrm{~h}$.

\section{7.2 Run SB-0676 with $100 \mathrm{Fe} / 3 \mathrm{Cu} / 4 \mathrm{~K} / 16 \mathrm{SiO} 2$ Catalyst}

For this slurry test, the catalyst was calcined at $700^{\circ} \mathrm{C}$ for $1 \mathrm{~h}$ in a furnace (flash calcination procedure). In order to achieve uniform heating during the calcination, the catalyst (total of 20 grams) was distributed evenly into four preheated crucibles each containing a thin layer of catalyst.

About $16 \mathrm{~g}$ of the calcined catalyst $(<270$ mesh in size) was loaded into the reactor together with $300 \mathrm{~g}$ of Durasyn 164 oil as the initial slurry medium. After the reduction with hydrogen at $240^{\circ} \mathrm{C}, 0.78 \mathrm{MPa}$ for $2 \mathrm{~h}$ (the standard conditions for catalyst $\mathrm{C}$ ), the catalyst was tested initially at $260^{\circ} \mathrm{C}, 1.48 \mathrm{MPa}$, syngas molar feed ratio of 0.67 and gas space velocity of 1.4 $\mathrm{N} 1 / \mathrm{g}$-cat/h. The $\mathrm{CO}$ and syngas conversions were stable at about 67 and $63 \%$, respectively 
(Figures $7 \mathrm{a}$ and $7 \mathrm{~b}$ ). The $\mathrm{H}_{2} / \mathrm{CO}$ usage ratio was about $0.55-0.56$ (Figure $7 \mathrm{c}$ ). Initial methane selectivity was relatively high, about $4.0 \mathrm{~mol} \%$, but it stayed below $4 \mathrm{~mol} \%$ during the remainder of the test (Figure 8a). The $\mathrm{C}_{1}+\mathrm{C}_{2}$ selectivity varied between 7.3 and 8.0 mol\%, whereas $\mathrm{C}_{2}-\mathrm{C}_{4}$ selectivity was about $14 \mathrm{~mol} \%$ (Figures $8 \mathrm{~b}$ and $8 \mathrm{c}$ ).

At $166 \mathrm{~h}$ on stream, the reaction pressure and feed gas space velocity were increased to 2.17 MPa and $1.8 \mathrm{Nl} / \mathrm{g}$-cat/h, respectively. This resulted in temporary increase of the $\mathrm{CO}$ and syngas conversions, followed by continued decrease afterwards. The CO conversion decreased from 68 to $61 \%$ during the next $130 \mathrm{~h}$ on stream, whereas the syngas conversion decreased from 64 to $57 \%$. During the same period of time methane selectivity decreased from 3.8 to $3.3 \mathrm{~mol} \%$, and $\left(\mathrm{C}_{1}+\mathrm{C}_{2}\right)$ hydrocarbon selectivity decreased from 7.2 to $6.5 \mathrm{~mol} \%$. The run was terminated after $305 \mathrm{~h}$ on stream. Major events for run SB-0676 are summarized in Table 2.

A major problem during the test was wax removal from the reactor. Wax withdrawal was slow even during the first $50 \mathrm{~h}$ on stream (when the slurry "wax" was mainly Durasyn-164 liquid oil), requiring the use of pressure drop of $0.7 \mathrm{MPa}$ across the filter (with pore size of $0.5 \mu \mathrm{m}$ ). The pressure drop was increased to $2.1 \mathrm{MPa}$ several days later to facilitate the wax removal. After $240 \mathrm{~h}$, it became virtually impossible to withdraw the wax from the reactor. After the test about $440 \mathrm{~g}$ of slurry was removed from the reactor, whereas normally this amount is about 250 $\mathrm{g}$, therefore, a large amount of product wax had accumulated in the reactor during the latter portion of the test.

After the test, the filter was removed and cleaned in an ultrasonic bath, but it still could not remove liquid from the reactor (low molecular weight hydrocarbon solvent - Varsol). This filter seems to be blocked. We plan to replace this filter with a new one with the average pore size of $2.0 \mu \mathrm{m}$ for future tests in the slurry $B$ reactor. 
Comparison of Results from Runs SB-0676, SB-2145 and SA-1665

Results from two tests SB-2145 (Quarterly Technical Progress Report for JulySeptember, 1995) and SB-2145 (Quarterly Technical Progress Report for April-June, 1995), in which the catalyst was calcined at $300^{\circ} \mathrm{C}$ for $5 \mathrm{~h}$, are compared with those obtained in run SB0676 in Figures 9 and 10. Figure 9 compares the catalyst activity among the three tests in terms of the apparent rate constant (assuming the first order reaction in hydrogen partial pressure). The catalyst calcined at $700^{\circ} \mathrm{C}$ (SB-0676) had significantly lower activity than the catalyst calcined at $300^{\circ} \mathrm{C}$ (runs SB-2145 and SB-2145). This trend is in agreement with the findings from the fixed bed reactor tests, and lower activity is mainly due to the loss of surface area during high temperature calcination (see Table 3). Methane and gaseous hydrocarbon selectivities were higher on the catalyst calcined at $700^{\circ} \mathrm{C}$ (Figure 10 , data at $1.48 \mathrm{MPa}$ only). However, they were stable with time, unlike those in runs SA-1665 and SB-2145 which increased with time and eventually led to similar values as those obtained in run SB-0676. This suggests that the catalyst calcined at high temperature has a more stable structure, which did not change during FT synthesis.

\section{8 Task 8 Catalyst Characterization}

III. 8.1 BET Measurement Results

Results of BET measurements illustrating the effect of calcination temperature on the pore size distribution of catalysts $\mathrm{B}\left(100 \mathrm{Fe} / 5 \mathrm{Cu} / 6 \mathrm{~K} / 24 \mathrm{SiO}_{2}\right.$, from batch-3) and $\mathrm{C}(100 \mathrm{Fe} / 3$ $\mathrm{Cu} / 4 \mathrm{~K} / 16 \mathrm{SiO}_{2}$, from batch- 4) are shown in Figures 11 and 12, respectively. The pore diameter varied between 2.0 and $20.0 \mathrm{~nm}$ for the catalysts studied (calcined from 300 to $700^{\circ} \mathrm{C}$ ). The pore size data clearly show that the pore diameter of the catalyst slightly increases with the increase in calcination temperature. In general, both the surface area and the pore volume decrease with either increase in calcination temperature or increasing time at a fixed calcination temperature (Table 3). The surface area of catalyst $\mathrm{C}\left(100 \mathrm{Fe} / 3 \mathrm{Cu} / 4 \mathrm{~K} / 16 \mathrm{SiO}_{2}\right.$ from batch 4$)$ decreased from 310 to $108 \mathrm{~m}^{2} / \mathrm{g}$-cat, whereas the surface area of catalyst $\mathrm{B}\left(100 \mathrm{Fe} / 5 \mathrm{Cu} / 6 \mathrm{~K} / 24 \mathrm{SiO}_{2}\right.$ 
from batch 3) decreased from 258 to $100 \mathrm{~m}^{2} / \mathrm{g}$-cat when the calcination temperature increased from 300 to $700^{\circ} \mathrm{C}$. The pore volumes of both catalysts decreased from about $0.5 \mathrm{~cm}^{3} / \mathrm{g}$ at $300^{\circ} \mathrm{C}$ to $0.3 \mathrm{~cm}^{3} / \mathrm{g}$ at calcination temperature of $700^{\circ} \mathrm{C}$.

III. 8. 2 XRD Measurement Results

II. 8. 2. 1 XRD Measurements of Catalyst Samples from Slurry Reactor Tests Conducted Under Task 6

Figure 13 illustrates changes in bulk iron phases with time on steam during run SA-0376 with catalyst $\mathrm{C}\left(100 \mathrm{Fe} / 3 \mathrm{Cu} / 4 \mathrm{~K} / 16 \mathrm{SiO}_{2}\right.$ from batch 4). Metallic iron $(\alpha-\mathrm{Fe})$ and small amounts of magnetite $\left(\mathrm{Fe}_{3} \mathrm{O}_{4}\right)$ were found (Figure 13-A) in the sample withdrawn immediately after the hydrogen reduction (TOS $=0 \mathrm{~h}$ ). During FT synthesis the relative amounts of iron carbide and magnetite increased with time on stream (Figures 13-B to 13-D), whereas the catalyst activity gradually decreased.

Figure 14 illustrates the effect of hydrogen reduction temperature and duration on bulk iron phases of catalyst $\mathrm{C}\left(100 \mathrm{Fe} / 3 \mathrm{Cu} / 4 \mathrm{~K} / 16 \mathrm{SiO}_{2}\right.$ from batch 4$)$. At a reduction temperature of $240^{\circ} \mathrm{C}$ and reduction time of $2 \mathrm{~h}$ catalyst C (run SB-2145) was reduced primarily to magnetite and possibly to $\alpha$-Fe (Figure 14-A). After the reduction at a higher temperature $\left(250^{\circ} \mathrm{C}\right.$ ) and longer duration $(4 \mathrm{~h})$ both magnetite and, to a smaller extent, metallic iron were found in the reduced sample (Figure 14-B). As the reduction temperature and time were increased further $\left(280^{\circ} \mathrm{C}, 8 \mathrm{~h}\right.$ ) the catalyst from run SA-0376 (Figure 14-C) was in the form of $\alpha$-Fe with small amounts of magnetite. Results show that the degree of reduction increases with the use of more severe reduction conditions.

\section{8.2. 2 XRD Measurements of Catalyst Samples from Fixed Bed and Slurry Reactor Studies Conducted Under Task 7}

Used catalyst samples from runs FB-2975, FA-2925 (Quarterly Technical Progress Report for October-December, 1995) and FB-0236 were characterized by X-ray diffraction. Prior to reaction tests the catalysts were calcined at different temperatures ranging from 300 to $700^{\circ} \mathrm{C}$ followed by reduction in hydrogen at $250^{\circ} \mathrm{C}$ for $4 \mathrm{~h}$. After that, they were tested in a fixed 
bed reactor for about 120 to $140 \mathrm{~h}$, and at the end of each run catalyst samples from the top and bottom portions of the bed were collected and analyzed by X-ray diffraction. The pseudohexagonal iron carbide $\left(\varepsilon^{\prime}-\mathrm{Fe}_{2.2} \mathrm{C}\right)$ was the only phase found in all the six samples (top and bottom portions) at the end of these three runs (Figure 15).

Figure 16 illustrates changes in bulk iron phases with time on stream during run SB-0676 with catalyst $\mathrm{C}\left(100 \mathrm{Fe} / 3 \mathrm{Cu} / 4 \mathrm{~K} / 16 \mathrm{SiO}_{2}\right)$ from batch 4 . This catalyst was calcined at $700^{\circ} \mathrm{C}$ for $1 \mathrm{~h}$ prior to testing. Magnetite was found in the sample withdrawn immediately after the hydrogen reduction (TOS=0 h) as shown in Figure 16-A. Both magnetite and the pseudohexagonal iron carbide were found in the samples withdrawn during FT synthesis (Figures 16-B to $16-\mathrm{D})$.

Figure 17 shows the effect of calcination temperature on the reduction behavior of Catalyst $\mathrm{C}\left(100 \mathrm{Fe} / 3 \mathrm{Cu} / 4 \mathrm{~K} / 16 \mathrm{SiO}_{2}\right.$ from batch 4$)$. Both the catalysts were reduced with hydrogen at $240^{\circ} \mathrm{C}$ for $2 \mathrm{~h}$. Both magnetite and, to a smaller extent, metallic iron were found after the reduction in the catalyst sample calcined at $300^{\circ} \mathrm{C}$ (run SB-2145, Figure 17-A). The catalyst calcined at $700^{\circ} \mathrm{C}$ (SB-0676) was reduced to magnetite only (Figure 17-B).

\section{8.3. Temperature Programmed Reduction (TPR) Measurements}

Temperature-programmed reduction (TPR) and isothermal reduction studies were performed using $5 \% \mathrm{H}_{2} / 95 \% \mathrm{~N}_{2}$ as reductant. In a typical TPR experiment about 10 to $20 \mathrm{mg}$ of catalyst was packed in a quartz reactor and purged with helium to remove the moisture from the catalyst sample. Then the catalyst sample was heated in a flow of $5 \% \mathrm{H}_{2} / 95 \% \mathrm{~N}_{2}$ (flow rate of 40 $\mathrm{ml} / \mathrm{min}$ ) from room temperature to $800^{\circ} \mathrm{C}$ at a heating rate of $20^{\circ} \mathrm{C} / \mathrm{min}$. In order to quantify the degree of reduction, $\mathrm{CuO}$ standard was used for the calibration of the peak areas. 
A typical TPR profile for the unpromoted iron sample is given in Figure 18-A, the two peaks in the thermogram correspond to the characteristic two-step reduction of $\mathrm{Fe}_{2} \mathrm{O}_{3}$ that was observed for most of the catalysts studied:

$$
\begin{aligned}
& 3 \mathrm{Fe}_{2} \mathrm{O}_{3}+\mathrm{H}_{2} \Leftrightarrow 2 \mathrm{Fe}_{3} \mathrm{O}_{4}+\mathrm{H}_{2} \mathrm{O} \\
& 2 \mathrm{Fe}_{3} \mathrm{O}_{4}+8 \mathrm{H}_{2} \Leftrightarrow 6 \mathrm{Fe}+8 \mathrm{H}_{2} \mathrm{O}
\end{aligned}
$$

\section{8. 3.1 Effect of Potassium Promotion}

The effect of potassium promoter on the reduction behavior in $\mathrm{H}_{2}$ of copper-free calcined iron catalysts is illustrated in Figure 18 (their degree of reduction results are summarized in Table 4). Potassium addition had virtually no effect on either the position or the area of the TPR peak at $380^{\circ} \mathrm{C}$ that corresponds to $\mathrm{Fe}_{3} \mathrm{O}_{4}$ formation. However, increasing levels of potassium promoter caused a marked increase in the reduction temperature (Figures 18-A to 18-D) for the second stage of the reduction process $\left(\mathrm{Fe}_{3} \mathrm{O}_{4}\right.$ to $\left.\alpha-\mathrm{Fe}\right)$. The reduction temperature maxima $\left(\mathrm{T}_{\mathrm{m}}\right)$ , for the second stage of reduction, for unpromoted iron sample (Figure $18-\mathrm{A}$ ) is about $595^{\circ} \mathrm{C}$, but it increased to about $630^{\circ} \mathrm{C}$ for the $100 \mathrm{Fe} / 1 \mathrm{~K}$ catalyst (Figure18-D). However, the total degree of reduction was not influenced by the potassium levels in the catalyst samples (Table 4). The results (from Figure 18 and Table 4) also show that the peak area ratio of the first and second peak is about 1:8. This is consistent with the theoretical value for complete reduction of iron oxide to zero valent iron, according to the two step process described by equations (1) and (2).

\section{8. 3. 2 Effect of Copper Promotion}

Figure 19 illustrates the effect of copper promotion on the reduction of iron oxide. The $100 \mathrm{Fe} / 0.3 \mathrm{Cu}$ catalyst has two peaks between 400 and $700^{\circ} \mathrm{C}$, indicating the presence of different types of iron phases in the sample. The addition of copper to the catalyst facilitates the reduction of iron oxide. The reduction temperature maxima $\left(\mathrm{T}_{\mathrm{m}}\right)$ for the first reduction step decreased from 360 to $260^{\circ} \mathrm{C}$ (Figures 19-B and 19-C) when the copper levels are increased from

0.3 to 3 parts per 100 parts of iron. With further increase in copper promotion $(100 \mathrm{Fe} / 5 \mathrm{Cu})$ the 
reduction temperature decreases to $230^{\circ} \mathrm{C}$ (Figure 19-D). The $100 \mathrm{Fe} / 5 \mathrm{Cu}$ catalyst also shows a second peak at $280^{\circ} \mathrm{C}$. The existence of two peaks $\left(T_{m}=230\right.$ and $\left.280^{\circ} \mathrm{C}\right)$ in the low temperature region may be attributed to the presence of two different kinds of iron oxide species in the sample. The position of the second temperature maxima, also shifts to lower temperatures with the addition of copper (Figures 19-A to 19-D).

\section{8. 3.3 Effects of Silica, Potassium and Calcium Oxide on the Reduction Behavior of Copper Promoted Iron Catalysts}

Figure 20 illustrates the effects of addition of silica, potassium and calcium oxide on the reduction behavior of copper promoted iron catalyst. Comparing Figures 20-B and 20-C, one can see that the first and the second peaks of iron reduction shift from $260^{\circ} \mathrm{C}$ to $330^{\circ} \mathrm{C}$ and $570^{\circ} \mathrm{C}$ to $630^{\circ} \mathrm{C}$, respectively, with addition of silica. Thus, the addition of silica inhibits the reduction of iron catalyst. From Figures $20-\mathrm{C}$ and $20-\mathrm{D}$ it follows that the addition of potassium to the doubly promoted iron catalyst $\left(100 \mathrm{Fe} / 3 \mathrm{Cu} / 16 \mathrm{SiO}_{2}\right)$ has virtually no effect on the reduction behavior of the iron. However, the addition of $\mathrm{CaO}$ to the triply promoted iron catalyst retards the first step of iron reduction (Figures 20-A and 20-D). The added silica and calcium oxide may be stabilizing or blocking the iron oxide species. It is also evident from literature (Jones and McNicol, 1986) that the standard free energy change $\left(\Delta \mathrm{G}^{\circ}\right)$ values for the reduction of calcium oxide and silica are high ( $350 \mathrm{~kJ} / \mathrm{mole}^{-1}$ for $\mathrm{CaO}$ and $\sim 175 \mathrm{~kJ} / \mathrm{mole}^{-1}$ for silica).

The qualitative trends observed in Figure 20 with the catalysts containing 3 parts of $\mathrm{Cu}$ per 100 parts of iron, are also seen with catalysts containing 5 parts of $\mathrm{Cu}$ (Figure 21).

\section{8. 4 Isothermal Reduction}

In isothermal reduction, catalyst samples of about 400 to $500 \mathrm{mg}$ were used. The temperature was ramped at a constant rate of $5^{\circ} \mathrm{C} / \mathrm{min}$ to a final temperature of $280^{\circ} \mathrm{C}$. Then the catalyst sample was maintained at this temperature for $8 \mathrm{~h}$ in a flow of $5 \% \mathrm{H}_{2} / 95 \% \mathrm{~N}_{2}(40$ $\mathrm{m} 1 / \mathrm{min})$. 


\section{8. 4. 1 Effect of Potassium Promoter}

Figure 22 illustrates the effect of potassium addition on the degree of reduction of iron. The results show that the degree of reduction increases rapidly up to a reduction time of about 250 minutes and then levels off with further increase in reduction time. Also, the results show that both the rate and the degree of reduction decrease with increase in potassium levels in the catalyst.

\section{8. 4. 2 Effects of Copper, Potassium and Silica Promoters}

Figure 23 demonstrates the effect of addition of silica and potassium promoters on the reduction behavior of an iron catalyst promoted with 3 parts of copper per 100 parts of iron. The results show that the addition of silica and potassium causes an increase in the overall rate and degree of reduction compared to that of copper only promoted catalyst. Since the addition of silica stabilizes or blocks the iron oxide species the observed increase in degree of reduction is contrary to the expected behavior for these catalysts. The total degree of reduction values are about $48 \%$ for the silica and copper containing catalysts (Figure 23). The total degree of reduction values obtained from TPR experiments are: $95 \%$ for $100 \mathrm{Fe} / 3 \mathrm{Cu} ; 92 \%$ for $100 \mathrm{Fe} / 3$ $\mathrm{Cu} / 16 \mathrm{SiO}_{2}$, and $74 \%$ for $100 \mathrm{Fe} / 3 \mathrm{Cu} / 16 \mathrm{SiO}_{2} / 4 \mathrm{~K}$ catalyst. Differences in the degree of reduction values are mainly due to the differences in reduction temperatures. In the TPR experiments the maximum reduction temperatures is about $800^{\circ} \mathrm{C}$ while the maximum reduction temperature during the isothermal reduction is $280^{\circ} \mathrm{C}$.

Figure 24 demonstrates the effect of addition of silica and potassium promoters on the reduction behavior of an iron catalyst promoted with 5 parts of copper per 100 parts of iron. Results show that the addition of silica and potassium causes an increase in the overall rate and degree of reduction compared to that of copper only promoted catalyst. From Figures 23 and 24 it appears that both series of catalysts exhibit the same type of behavior during isothermal reduction at $280^{\circ} \mathrm{C}$. 


\section{8.5 TGA Measurement Results}

Isothermal reduction in thermogravimetric analysis (TGA) experiments was conducted using approximately $20 \mathrm{mg}$ catalyst samples. The catalyst sample was purged with helium (40 $\mathrm{ml} / \mathrm{min}$ ) and temperature was ramped at a rate of $5^{\circ} \mathrm{C} / \mathrm{min}$ from a room temperature to $280^{\circ} \mathrm{C}$. Then the helium flow was switched to hydrogen (99.995\% purity) at $40 \mathrm{ml} / \mathrm{min}$, and the temperature was maintained at $280^{\circ} \mathrm{C}$ for a total period of $8 \mathrm{~h}$. The degree of reduction was calculated from the weight loss vs. time data.

Figure 25 shows the effects of silica, potassium and calcium oxide on the rate and degree of reduction of iron catalysts promoted with 3 parts of copper per 100 parts of iron. The degree of reduction (open circles) of the $100 \mathrm{Fe} / 3 \mathrm{Cu}$ catalyst increased with time until about 320 minutes and then leveled off with further increase in reduction time. The degree of reduction of copper promoted iron catalyst decreased from about $85 \%$ to $45 \%$ when 16 parts of silica was added (solid circles). These results show that the reduction of copper promoted iron catalyst was inhibited by addition of silica, suggesting an interaction between the metal and silica, as proposed by many investigators (Dry, 1981; Anderson, 1984; Lund and Dumesic, 1981). The addition of potassium and calcium oxide to the doubly promoted (with 3 parts $\mathrm{Cu}$ and 16 parts silica) did not have much effect on either the rate or the degree of reduction.

Figure 26 shows the effects of silica, potassium and calcium oxide on the rate and degree of reduction of iron catalysts promoted with 5 parts of copper per 100 parts of iron. The results show that both the rate and the degree of reduction of copper promoted catalysts decrease with the addition of silica, potassium and calcium oxide promoters. The degree of reduction of 100 $\mathrm{Fe} / 5 \mathrm{Cu}$ catalyst decreased from about $90 \%$ to about $45 \%$ with the addition of 24 parts of silica. The degree of reduction was further decreased with the addition of calcium oxide to about $34 \%$ (solid squares).

There are some discrepancies in numerical values of the degree of reduction values obtained from three different reduction methods, namely TGA (isothermal), TPR and isothermal reduction in the TPR apparatus. Table 5 summarizes the effect of various promoters on the 
degree of reduction of iron catalysts. The degree of reduction of unpromoted iron oxide is about $62 \%$ as determined by TPR experiment. Isothermal reduction experiments are in progress for the unpromoted iron catalyst. The degree of reduction of copper promoted catalyst $(100 \mathrm{Fe} / 3 \mathrm{Cu})$ from TGA experiment is about $86 \%$ which is comparable to the value (95\%) obtained from TPR (non isothermal) experiment. However, the value obtained from the TPR apparatus under isothermal conditions is only $19 \%$, and is much lower than the value determined from TGA experiment under isothermal conditions. Differences between TGA and TPR-isothermal experimental results may be due to the differences in the partial pressures of the reducing gas (pure hydrogen in TGA experiments vs. 5\% hydrogen in the TPR unit), and the use of different amounts of catalyst samples in these two types of experiments.

The same trends, namely significantly higher degrees of reduction during isothermal reduction in the TGA unit in comparison to the TPR unit, were observed with all other catalysts (Table 5). We plan to examine this issue in future experiments.

\section{References}

Jones, A. and McNicol, B. "Theoretical Aspects" In Temperature-Programmed Reduction for Solid Materials Characterization; Marcel Dekker, Inc: New York, 1986, p. 13.

Anderson, R. B. The Fischer-Tropsch Synthesis; Academic Press: Orlando, Fla., 1984.

Dry, M. E " The Fischer-Tropsch Synthesis" In Catalysis Science and Technology Vol. 1; Anderson, J. R.; Boudart, M., Eds.; Springer-Verlag: New York, 1981, pp. 159-255.

Lund, C. R. F. and Dumesic, J. A. " Strong Oxide-Oxide Interactions in Silica-Supported $\mathrm{Fe}_{3} \mathrm{O}_{4} "$. J. Catal. 1981, 69, 32-43. 


\section{9 Catalyst Testing in a Bubble Column Slurry Reactor}

The work on this task is not scheduled to begin yet. No activity to report.

III. 10 Scale-up of Catalyst Synthesis Procedure

The work on this task is not scheduled to begin yet. No activity to report.

Plans for the Next Quarter

During the next quarter we plan to: (a) continue with testing of catalysts under Tasks 6 and 7 of the contract, and (b) continue with catalyst characterization of catalysts at various stages of usage (Task 8). 
Table 1. Major Events in Run SA-0376 with $100 \mathrm{Fe} / 3 \mathrm{Cu} / 4 \mathrm{~K} / 16 \mathrm{SiO} 2$ Catalyst (batch 4) $\operatorname{TOS}(\mathrm{h})$ Event

Slurry loading: $306 \mathrm{~g}$ of Durasyn 164 oil, $18.5 \mathrm{~g}$ of catalyst (particle size $<270$ mesh)

Catalyst pretreatment: $\mathrm{H}_{2}, 280^{\circ} \mathrm{C}, 0.78 \mathrm{MPa}$ for $8 \mathrm{~h}$

Slurry sample withdrawal: $13 \mathrm{~g}$ slurry, $0.75 \mathrm{~g}$ catalyst

Wax withdrawal through filter: $13 \mathrm{~g}$ of wax

0 Initiate synthesis gas flow, achieve process conditions: $\mathrm{T}=260^{\circ} \mathrm{C}, \mathrm{P}=1.48 \mathrm{MPa}$, $\mathrm{SV}=1.4 \mathrm{Nl} / \mathrm{g}$-cat $/ \mathrm{h},\left(\mathrm{H}_{2} / \mathrm{CO}\right)=0.67$

134 Slurry sample withdrawal: $14.2 \mathrm{~g}$ slurry, $0.75 \mathrm{~g}$ catalyst

159 Change space velocity to $\mathrm{SV}=2.3 \mathrm{Nl} / \mathrm{g}$-cat/h

230 Slurry sample withdrawal: $12.7 \mathrm{~g}$ slurry, $0.65 \mathrm{~g}$ catalyst

254 Change process conditions: $\mathrm{P}=2.17 \mathrm{MPa}, \mathrm{SV}=2.05 \mathrm{Nl} / \mathrm{g}$-cat $/ \mathrm{h}$

$350 \quad$ Slurry sample withdrawal: $30 \mathrm{~g}$ slurry, $1.0 \mathrm{~g}$ catalyst

End of run: $264 \mathrm{~g}$ slurry recovered from the reactor

Wax and catalyst removed during the run: $593 \mathrm{~g}$ wax, $3.2 \mathrm{~g}$ catalyst 
Table 2. Major Events in Run SB-0676 with $100 \mathrm{Fe} / 3 \mathrm{Cu} / 4 \mathrm{~K} / 16 \mathrm{SiO} 2$ Catalyst (batch 4)

TOS (h)

Event

Slurry loading: $304 \mathrm{~g}$ of Durasyn 164 oil, $15.8 \mathrm{~g}$ of catalyst (particle size $<270$ mesh)

Catalyst pretreatment: $\mathrm{H}_{2}, 240^{\circ} \mathrm{C}, 0.78 \mathrm{MPa}$ for $2 \mathrm{~h}$

Slurry sample withdrawal: $13 \mathrm{~g}$ slurry, $0.65 \mathrm{~g}$ catalyst

Wax withdrawal through filter: $5.2 \mathrm{~g}$ of wax

0 Initiate synthesis gas flow, achieve process conditions: $\mathrm{T}=260^{\circ} \mathrm{C}, \mathrm{P}=1.48 \mathrm{MPa}$, $\mathrm{SV}=1.4 \mathrm{Nl} / \mathrm{g}$-cat $/ \mathrm{h},\left(\mathrm{H}_{2} / \mathrm{CO}\right)=0.67$

120 Slurry sample withdrawal: $11 \mathrm{~g}$ slurry, $0.6 \mathrm{~g}$ catalyst

166 Change process conditions: $\mathrm{P}=2.17 \mathrm{MPa}, \mathrm{SV}=1.8 \mathrm{Nl} / \mathrm{g}-\mathrm{cat} / \mathrm{h}$

221 Slurry sample withdrawal: $26 \mathrm{~g}$ slurry, $1.2 \mathrm{~g}$ catalyst

305 Slurry sample withdrawal: $28.4 \mathrm{~g}$ slurry, $1.0 \mathrm{~g}$ catalyst

305 End of run: $438 \mathrm{~g}$ slurry recovered from the reactor

Wax and catalyst removed during the run: $78 \mathrm{~g}$ wax, $3.45 \mathrm{~g}$ catalyst 
Table 3. Effect of Calcination Conditions on the Textural Properties of Catalysts $\mathrm{C}$ $\left(100 \mathrm{Fe} / 3 \mathrm{Cu} / 4 \mathrm{~K} / 16 \mathrm{SiO}_{2}\right)$ and $\mathrm{B}(100 \mathrm{Fe} / 5 \mathrm{Cu} / 6 \mathrm{~K} / 24 \mathrm{SiO} 2)$.

\begin{tabular}{|c|c|c|c|}
\hline \multirow[t]{2}{*}{ Calcination Conditions } & \multicolumn{2}{|c|}{ BET Surface Area $\left(\mathrm{m}^{2} / \mathrm{g}\right)$} & \multirow{2}{*}{$\begin{array}{c}\text { Pore Volume } \\
\mathrm{Cm}^{3 / \mathrm{g}} \\
\end{array}$} \\
\hline & Single Point & BET Plot & \\
\hline \multicolumn{4}{|c|}{$100 \mathrm{Fe} / 3 \mathrm{Cu} / 4 \mathrm{~K} / 16 \mathrm{SiO}_{2}$, batch $4(\mathrm{S3416-4})$} \\
\hline $300^{\circ} \mathrm{C}$ for 5 hours & 310 & 306 & 0.45 \\
\hline $400^{\circ} \mathrm{C}$ for 5 hours & 263 & 268 & 0.42 \\
\hline $500^{\circ} \mathrm{C}$ for 5 hours & 183 & 188 & 0.36 \\
\hline $500^{\circ} \mathrm{C}$ for 30 minutes & 233 & & \\
\hline $500^{\circ} \mathrm{C}$ for 60 minutes & 231 & 216 & 0.40 \\
\hline $700^{\circ} \mathrm{C}$ for 30 minutes & 118 & & \\
\hline $700^{\circ} \mathrm{C}$ for 60 minutes & 108 & 106 & 0.30 \\
\hline \multicolumn{4}{|c|}{$100 \mathrm{Fe} / 5 \mathrm{Cu} / 6 \mathrm{~K} / 24 \mathrm{SiO}_{2}$, batch $3(\mathrm{~S} 5624-3)$} \\
\hline $300^{\circ} \mathrm{C}$ for 5 hours & 258 & 284 & 0.51 \\
\hline $400{ }^{\circ} \mathrm{C}$ for 5 hours & 271 & 253 & 0.48 \\
\hline $500{ }^{\circ} \mathrm{C}$ for 5 hours & 219 & 193 & 0.43 \\
\hline $500^{\circ} \mathrm{C}$ for 60 minutes & 227 & 212 & 0.46 \\
\hline $700^{\circ} \mathrm{C}$ for 30 minutes & 115 & 108 & 0.33 \\
\hline $700^{\circ} \mathrm{C}$ for 60 minutes & 100 & 96 & 0.33 \\
\hline
\end{tabular}


Table 4. Summary of Results from TPR Scans *

\begin{tabular}{ccccc}
\hline Sample & \multicolumn{2}{c}{ Peak Position $\left({ }^{\circ} \mathrm{C}\right)$} & Degree of Reduction (\%) \\
\hline & $\begin{array}{c}\text { Fisrt Stage } \\
\text { Reduction } \\
\text { Peaks }\end{array}$ & $\begin{array}{c}\text { Second Stage } \\
\text { Reduction Peaks }\end{array}$ & $\begin{array}{c}\text { Based on } \\
\text { First Stage } \\
\text { Peak }(s)\end{array}$ & $\begin{array}{c}\text { Based on First and } \\
\text { Second Stage Peaks }\end{array}$ \\
\hline $100 \mathrm{Fe}$ & 307,360 & 595 & $3.0,12.0$ & 61.7 \\
$100 \mathrm{Fe} / 0.2 \mathrm{~K}$ & 380 & 610 & 11.6 & 86.1 \\
$100 \mathrm{Fe} / 0.5 \mathrm{~K}$ & 384 & 620 & 10.4 & 90.8 \\
$100 \mathrm{Fe} / 1 \mathrm{~K}$ & 384 & 632 & 10.5 & 90.4 \\
$100 \mathrm{Fe} / 0.3 \mathrm{Cu}$ & 360 & 505,610 & 15.2 & $48.7,66.9$ \\
$100 \mathrm{Fe} / 3 \mathrm{Cu}$ & 260 & 560 & 9.4 & 95.0 \\
$100 \mathrm{Fe} / 5 \mathrm{Cu}$ & 240,280 & 565 & $7.5,11.1$ & 95.0 \\
$100 \mathrm{Fe} / 3 \mathrm{Cu} / 16 \mathrm{SiO}_{2}$ & 320 & 595 & 30.3 & 91.9 \\
$100 \mathrm{Fe} / 5 \mathrm{Cu} / 24 \mathrm{SiO} 2$ & 312 & 595 & 30.0 & 97.0 \\
$100 \mathrm{Fe} / 3 \mathrm{Cu} / 4 \mathrm{~K} / 16 \mathrm{SiO}_{2}$ & 320 & 580 & 23.8 & 74.1 \\
$100 \mathrm{Fe} / 5 \mathrm{Cu} / 6 \mathrm{~K} / 24 \mathrm{SiO}_{2}$ & 320 & 565 & 30.0 & 80.2 \\
$100 \mathrm{Fe} / 3 \mathrm{Cu} / 4 \mathrm{~K} / 6 \mathrm{Ca} / 16 \mathrm{SiO}_{2}$ & 317,350 & 610 & $4.9,14.0$ & 93.3 \\
$100 \mathrm{Fe} / 5 \mathrm{Cu} / 6 \mathrm{~K} / 6 \mathrm{Ca} / 24 \mathrm{SiO}_{2}$ & 340,370 & 630 & 5.9 & 85.7 \\
\hline
\end{tabular}

$*$ Experimental Conditions: Rate of Heating $=20^{\circ} \mathrm{C} / \mathrm{min}$; Reducing Gas Composition $=5 \% \mathrm{H}_{2} / 95 \% \mathrm{~N}_{2}$, Flow Rate $=40 \mathrm{ml} / \mathrm{min}$; Catalyst Weight $=10-20 \mathrm{mg}$; 
Table 5. Effect of the Addition of Copper, Potassium and Silica on the Degree of Reduction

\begin{tabular}{cccc}
\hline Catalyst & \multicolumn{3}{c}{ Degree of Reduction } \\
& TGA Isothermal & TPR Isothermal & TPR \\
\hline $100 \mathrm{Fe}$ & - & - & 61.7 \\
$100 \mathrm{Fe} / 3.0 \mathrm{Cu}$ & 86.5 & 19.4 & 95.0 \\
$100 \mathrm{Fe} / 3 \mathrm{Cu} / 16 \mathrm{SiO} 2$ & 47.7 & 25.0 & 91.9 \\
$100 \mathrm{Fe} / 3 \mathrm{Cu} / 4 \mathrm{~K} / 16 \mathrm{SiO}_{2}$ & 48.1 & 22.1 & 74.1 \\
$100 \mathrm{Fe} / 3 \mathrm{Cu} / 4 \mathrm{~K} / 6 \mathrm{Ca} / 16 \mathrm{SiO} 2$ & 46.2 & - & 93.3 \\
$100 \mathrm{Fe} / 5.0 \mathrm{Cu}$ & 88.5 & 20.9 & 95.0 \\
$100 \mathrm{Fe} / 5 \mathrm{Cu} / 24 \mathrm{SiO} 2$ & 47.0 & 27.8 & 97.0 \\
$100 \mathrm{Fe} / 5 \mathrm{Cu} / 4 \mathrm{~K} / 24 \mathrm{SiO}_{2}$ & 47.3 & 21.1 & 80.2 \\
$100 \mathrm{Fe} / 5 \mathrm{Cu} / 6 \mathrm{~K} / 6 \mathrm{Ca} / 24 \mathrm{SiO}_{2}$ & 34.5 & - & 85.7 \\
\hline
\end{tabular}



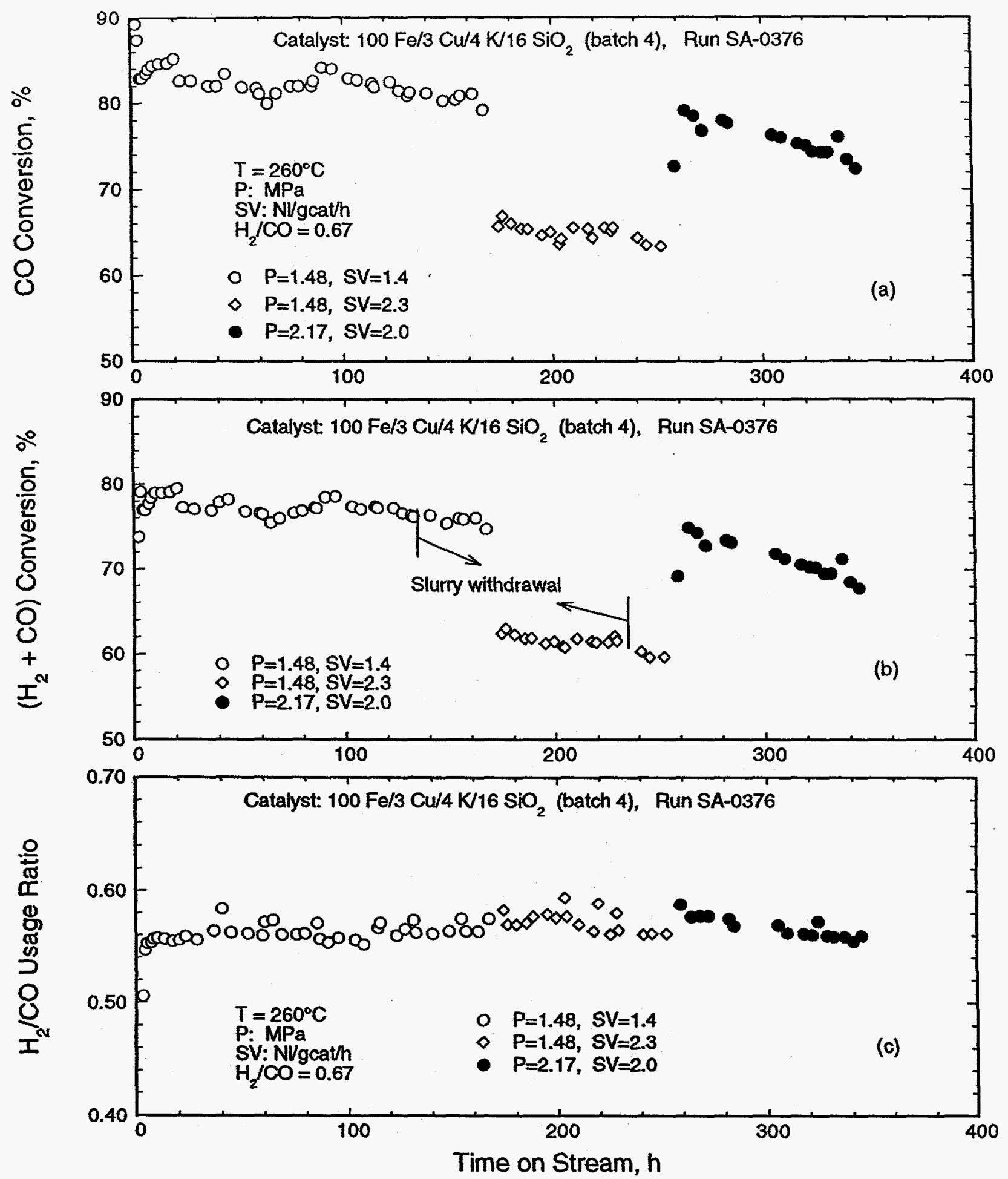

Figure 1. Variation in (a) CO conversion, (b) $\left(\mathrm{H}_{2}+\mathrm{CO}\right)$ conversion, and (c) $\mathrm{H}_{2} / \mathrm{CO}$ usage ratio with time on stream in run SA-0376 with the $100 \mathrm{Fe} / 3 \mathrm{Cu} / 4 \mathrm{~K} / 16 \mathrm{SiO} 2$ catalyst. 

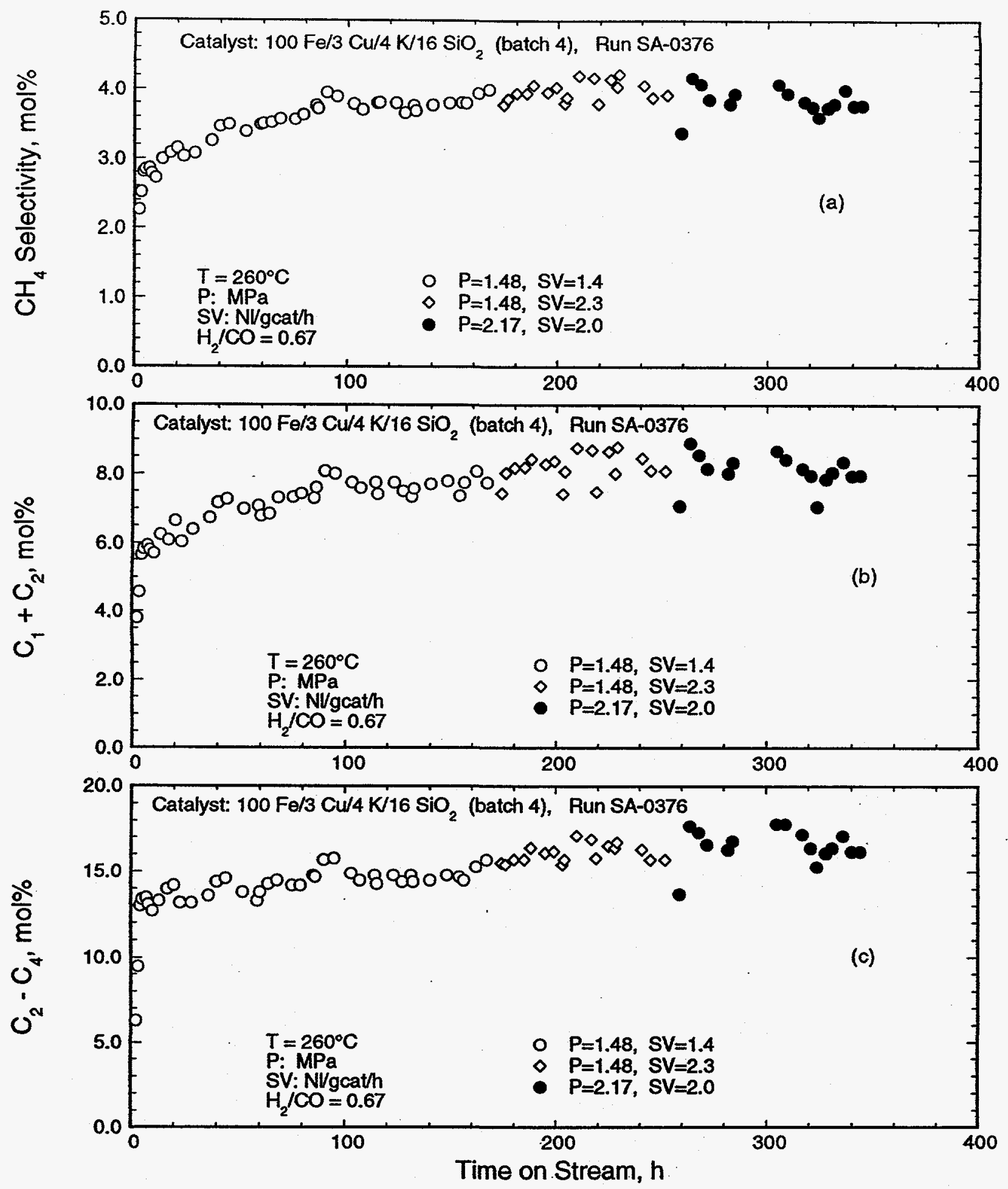

Figure 2. Variation in (a) methane selectivity, (b) $\mathrm{C}_{1}+\mathrm{C}_{2}$ selectivity and (c) $\mathrm{C}_{2}-\mathrm{C}_{4}$ selectivity with time on stream in run SA-0376 with the $100 \mathrm{Fe} / 3 \mathrm{Cu} / 4 \mathrm{~K} / 16 \mathrm{SiO}_{2}$ catalyst. 


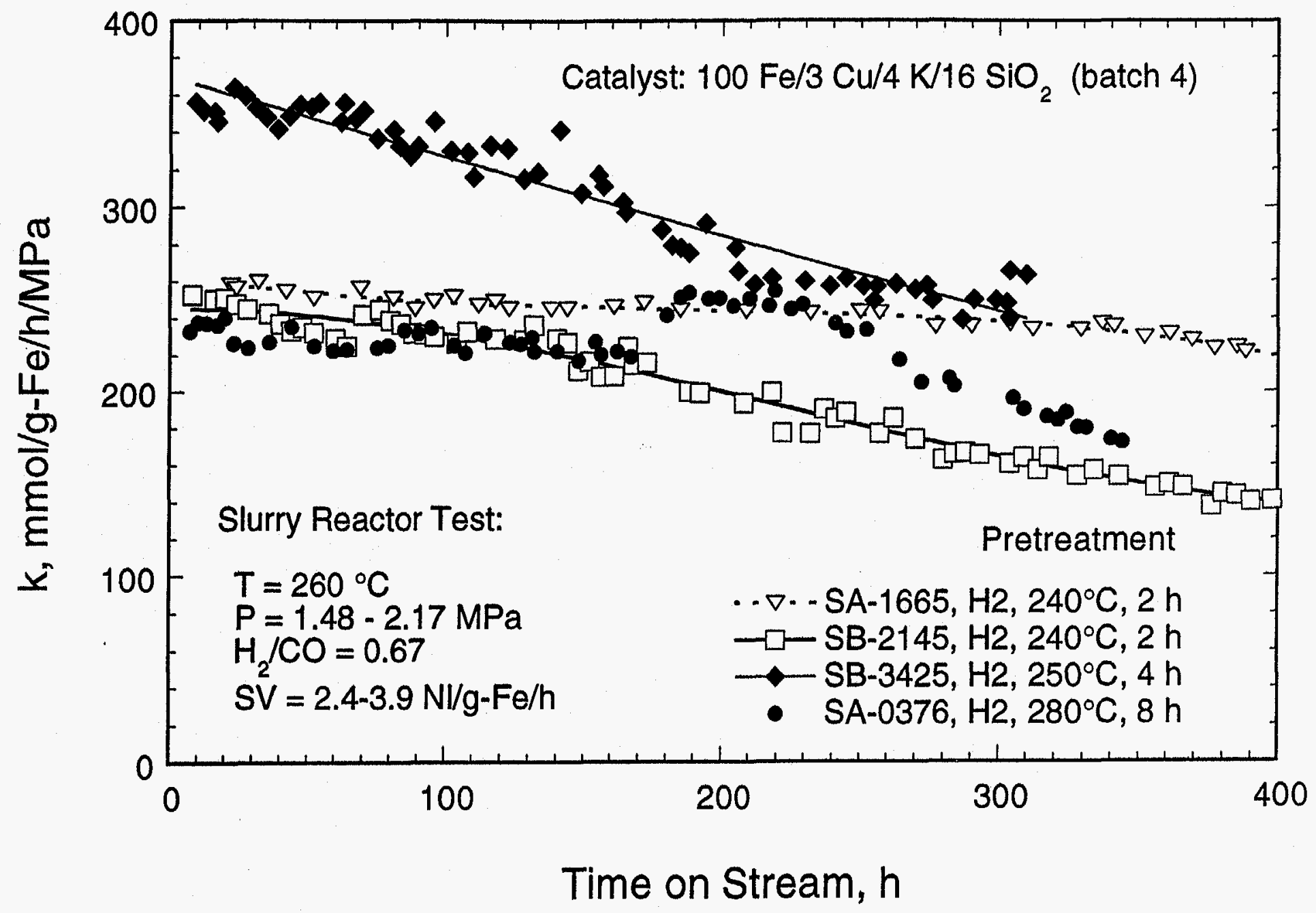

Figure 3. Comparison of an apparent first order reaction rate constant among runs SA-1665, SB-2145, SB3425 and SA-0376 with the $100 \mathrm{Fe} / 3 \mathrm{Cu} / 4 \mathrm{~K} / 16 \mathrm{SiO}_{2}$ catalyst using different pretreatment procedures. 

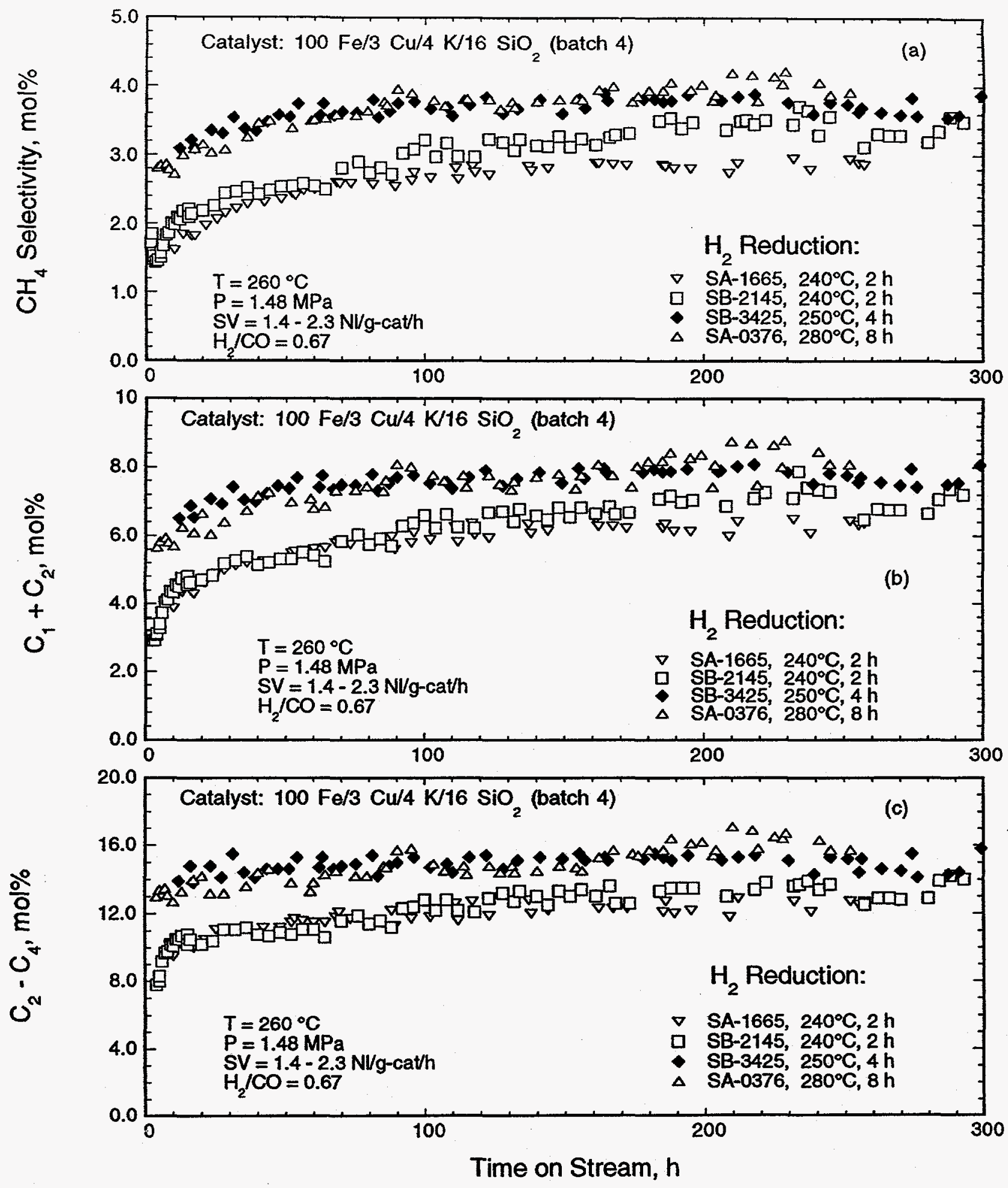

Figure 4. Comparison of (a) methane selectivity, (b) $\mathrm{C}_{1}+\mathrm{C}_{2}$ selectivity and (c) $\mathrm{C}_{2}-\mathrm{C}_{4}$ selectivity among runs SA-1665, SB-2145, SB-3425 and SA-0376 with the $100 \mathrm{Fe} / 3 \mathrm{Cu} / 4$ $\mathrm{K} / 16 \mathrm{SiO}_{2}$ catalyst. 

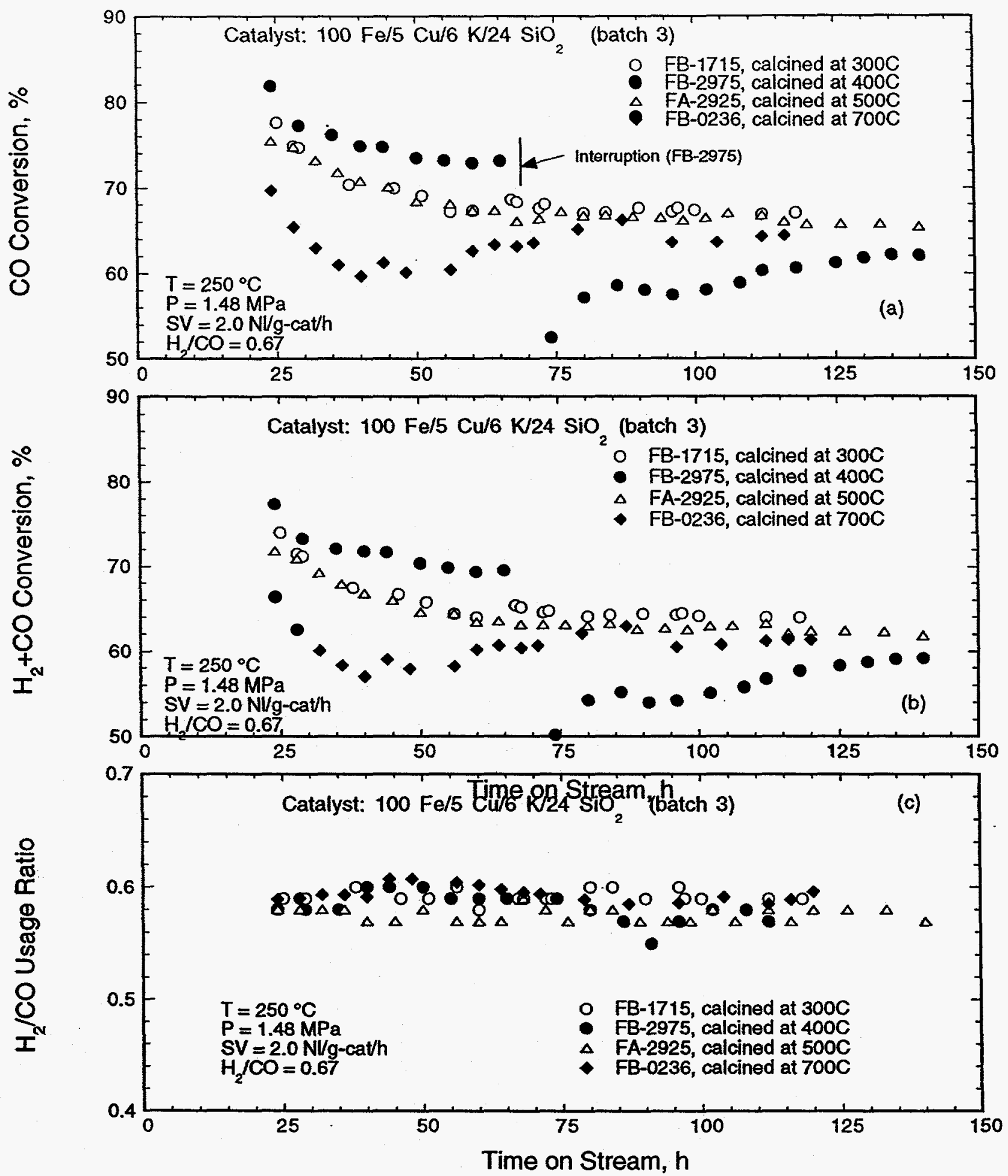

Figure 5. Effect of calcination temperature on (a) CO conversion, (b) $\left(\mathrm{H}_{2}+\mathrm{CO}\right)$ syngas conversion, and (c) $\mathrm{H}_{2} / \mathrm{CO}$ usage ratio in $\mathrm{FBR}$ tests with the $100 \mathrm{Fe} / 5 \mathrm{Cu} / 6 \mathrm{~K} / 24 \mathrm{SiO}_{2}$ catalyst. 

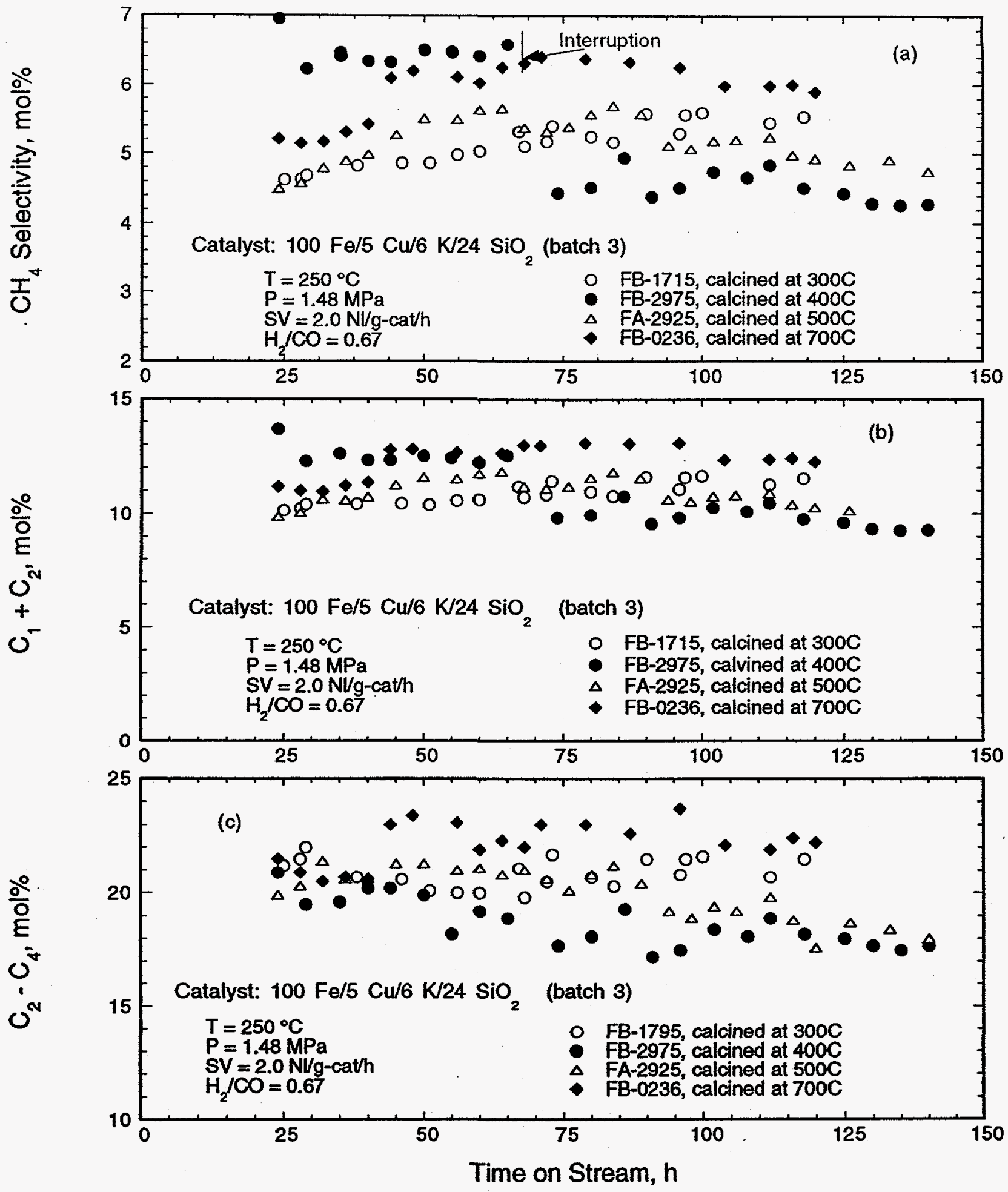

Figure 6. Effect of calcination conditions on (a) methane selectivity, (b) $\mathrm{C}_{1}+\mathrm{C}_{2}$ selectivity and (c) $\mathrm{C}_{2}-\mathrm{C}_{4}$ selectivity in FBR tests with the $100 \mathrm{Fe} / 3 \mathrm{Cu} / 4 \mathrm{~K} / 16 \mathrm{SiO} 2$ catalyst. 

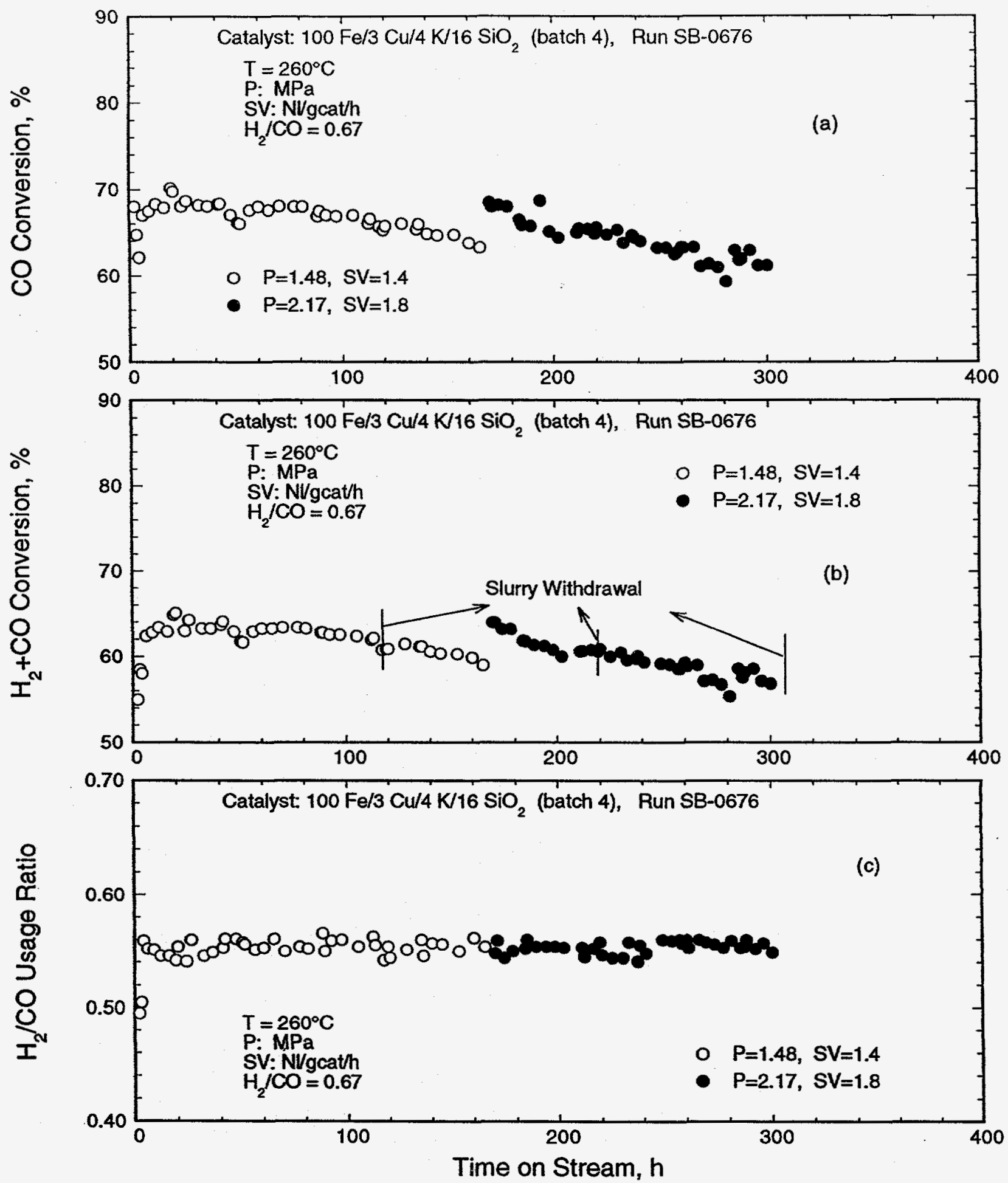

Figure 7. Change in (a) $\mathrm{CO}$ conversion, (b) $\left(\mathrm{H}_{2}+\mathrm{CO}\right.$ ) conversion, and (c) $\mathrm{H}_{2} / \mathrm{CO}$ usage ratio with time on stream in run SB-0676 with the $100 \mathrm{Fe} / 3 \mathrm{Cu} / 4 \mathrm{~K} / 16 \mathrm{SiO} 2$ catalyst. 

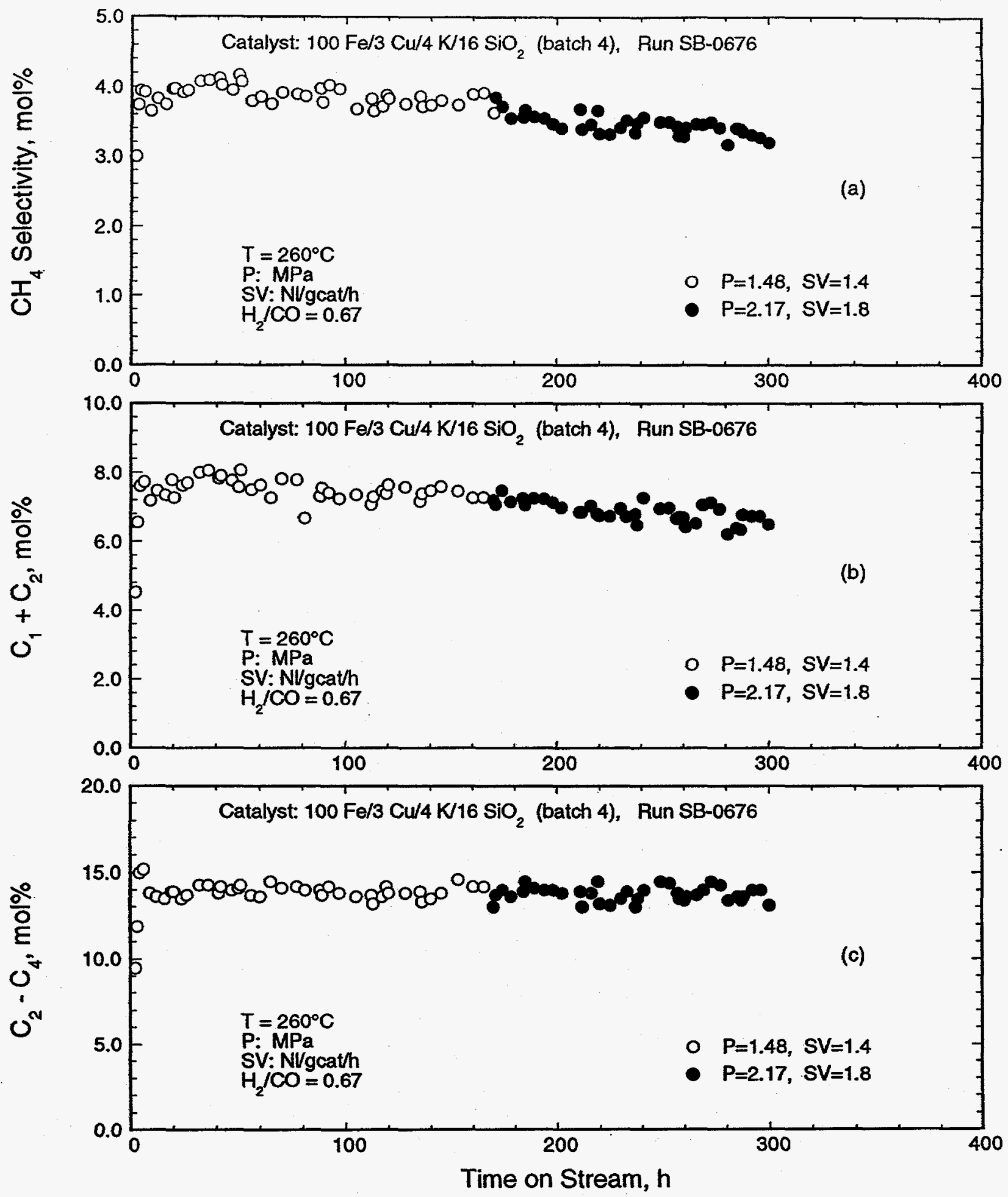

Figure 8. Change in (a) methane selectivity, (b) $\mathrm{C}_{1}+\mathrm{C}_{2}$ selectivity and (c) $\mathrm{C}_{2}-\mathrm{C}_{4}$ selectivity with time on stream in run SB-0676 with the $100 \mathrm{Fe} / 3 \mathrm{Cu} / 4 \mathrm{~K} / 16 \mathrm{SiO}_{2}$ catalyst. 


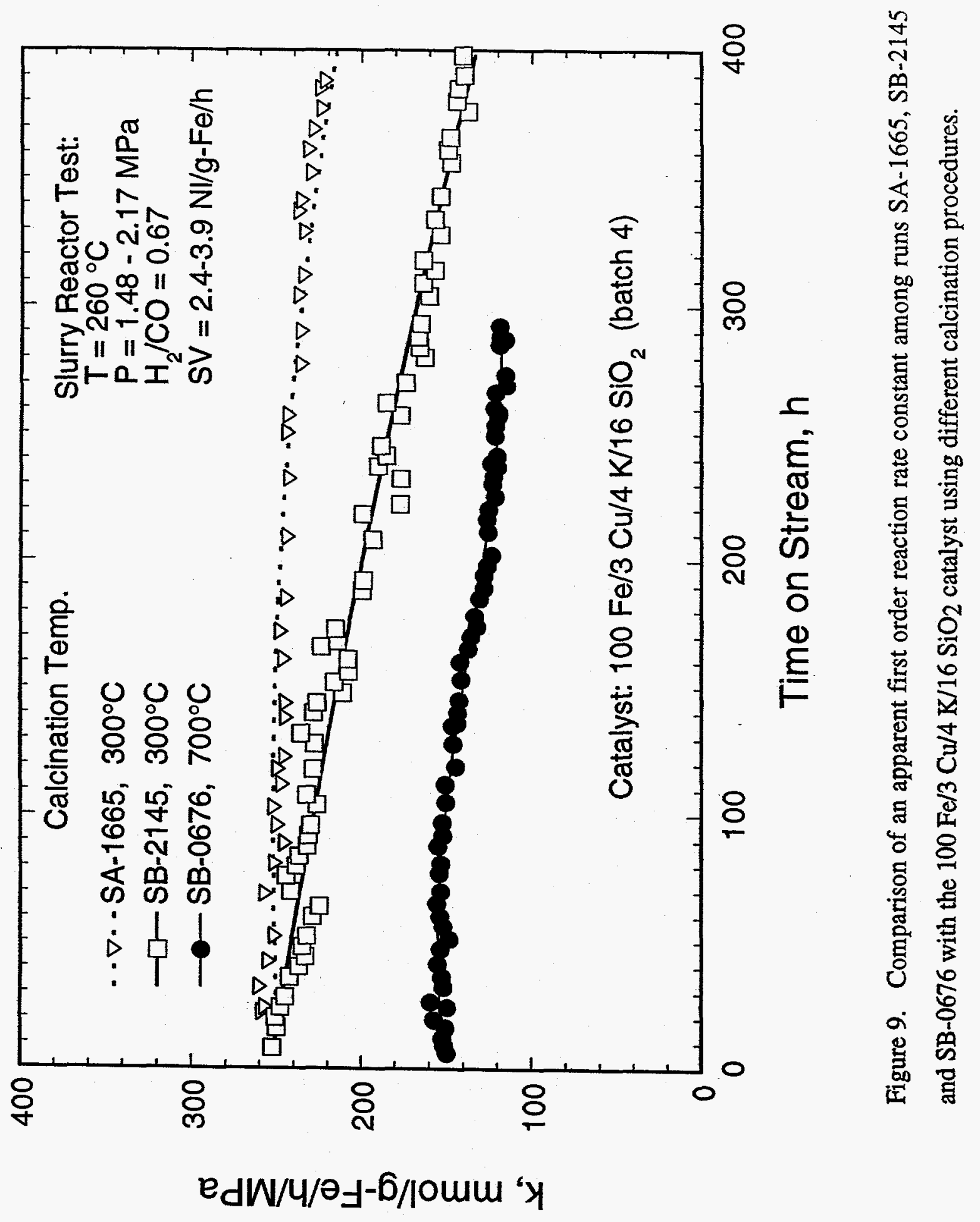



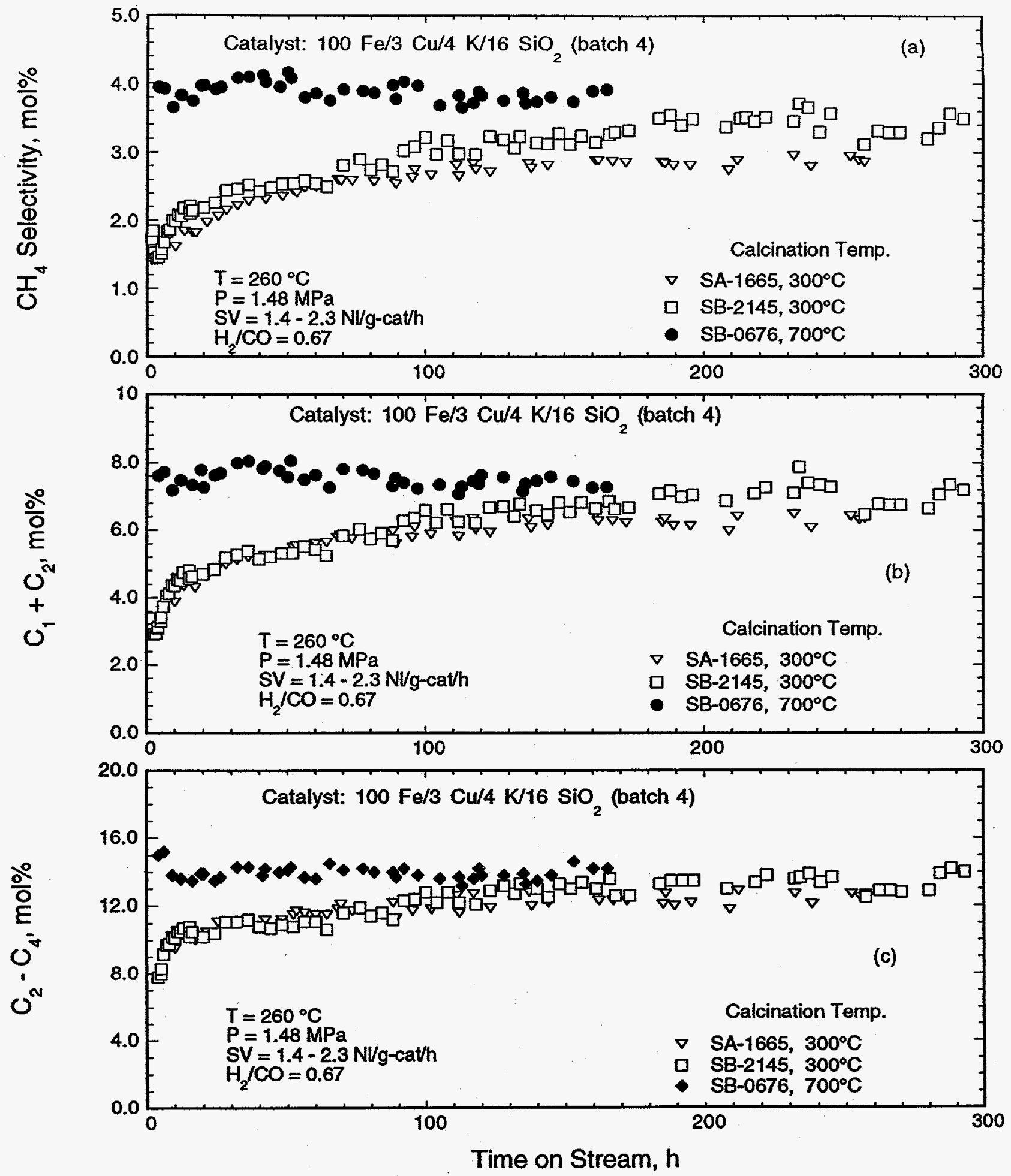

Figure 10. Comparison of (a) methane selectivity, (b) $\mathrm{C}_{1}+\mathrm{C}_{2}$ selectivity and (c) $\mathrm{C}_{2}-\mathrm{C}_{4}$ selectivity among runs SA-1665, SB-2145 and SB-0676 with the $100 \mathrm{Fe} / 3 \mathrm{Cu} / 4 \mathrm{~K} / 16 \mathrm{SiO} 2$ catalyst. 


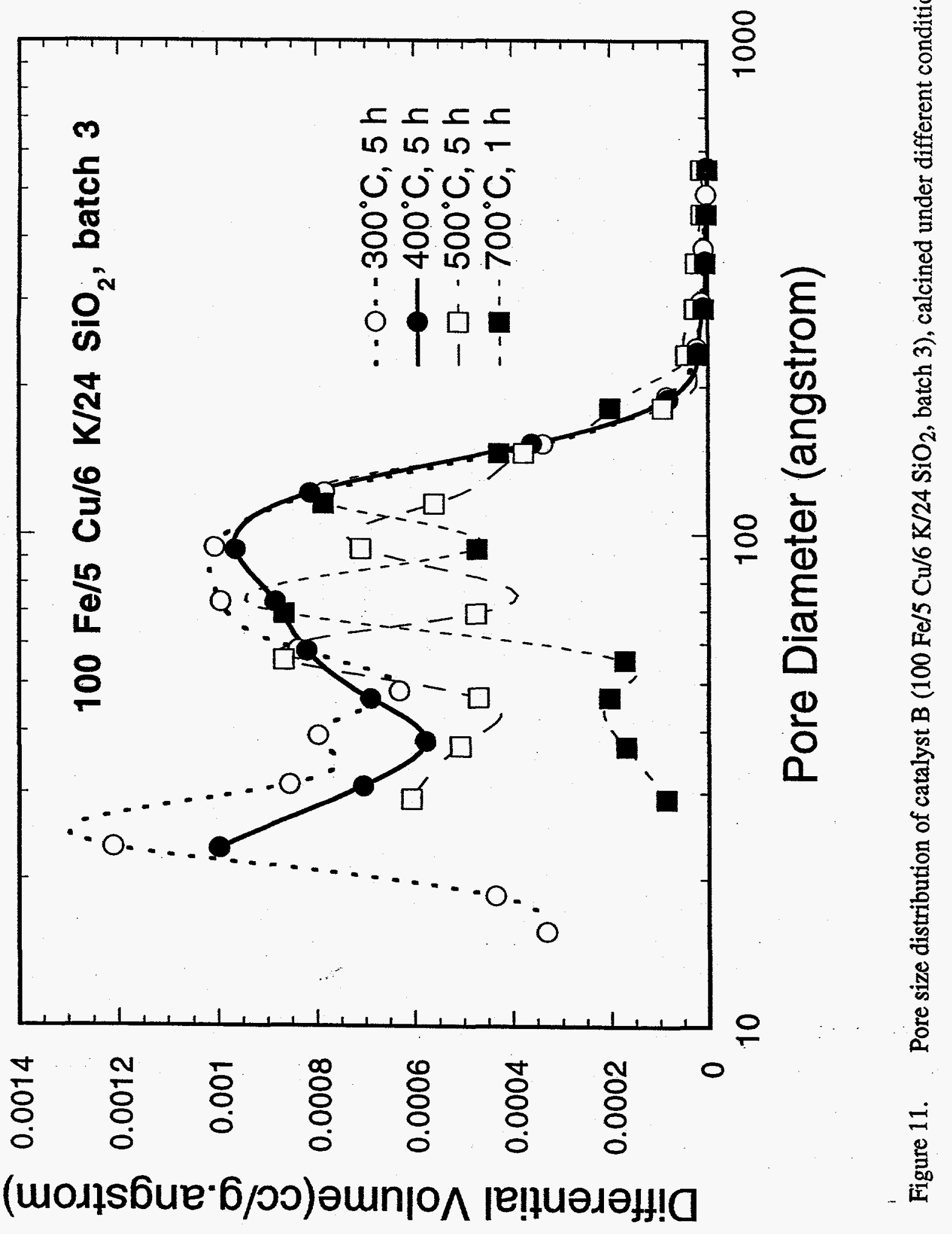




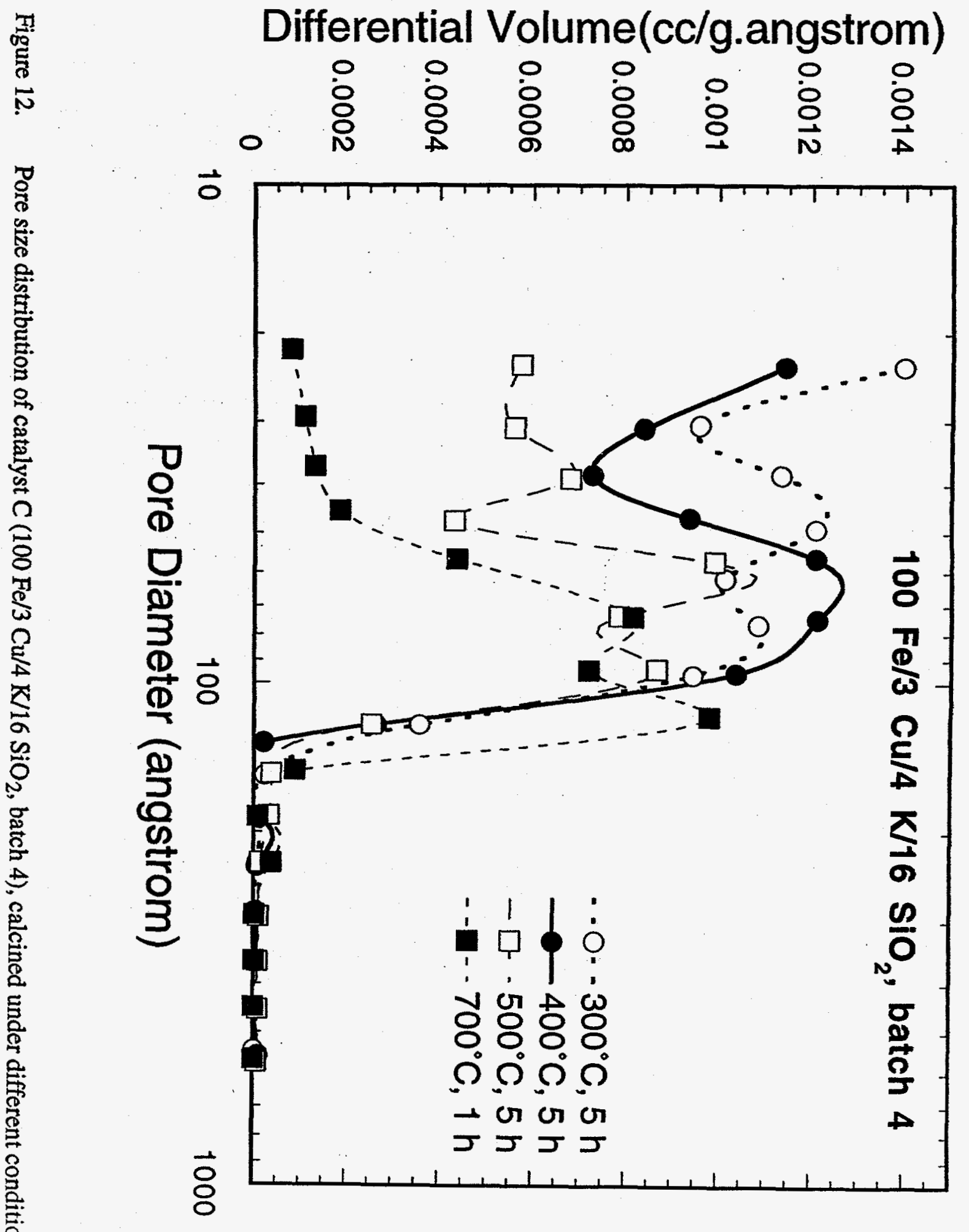




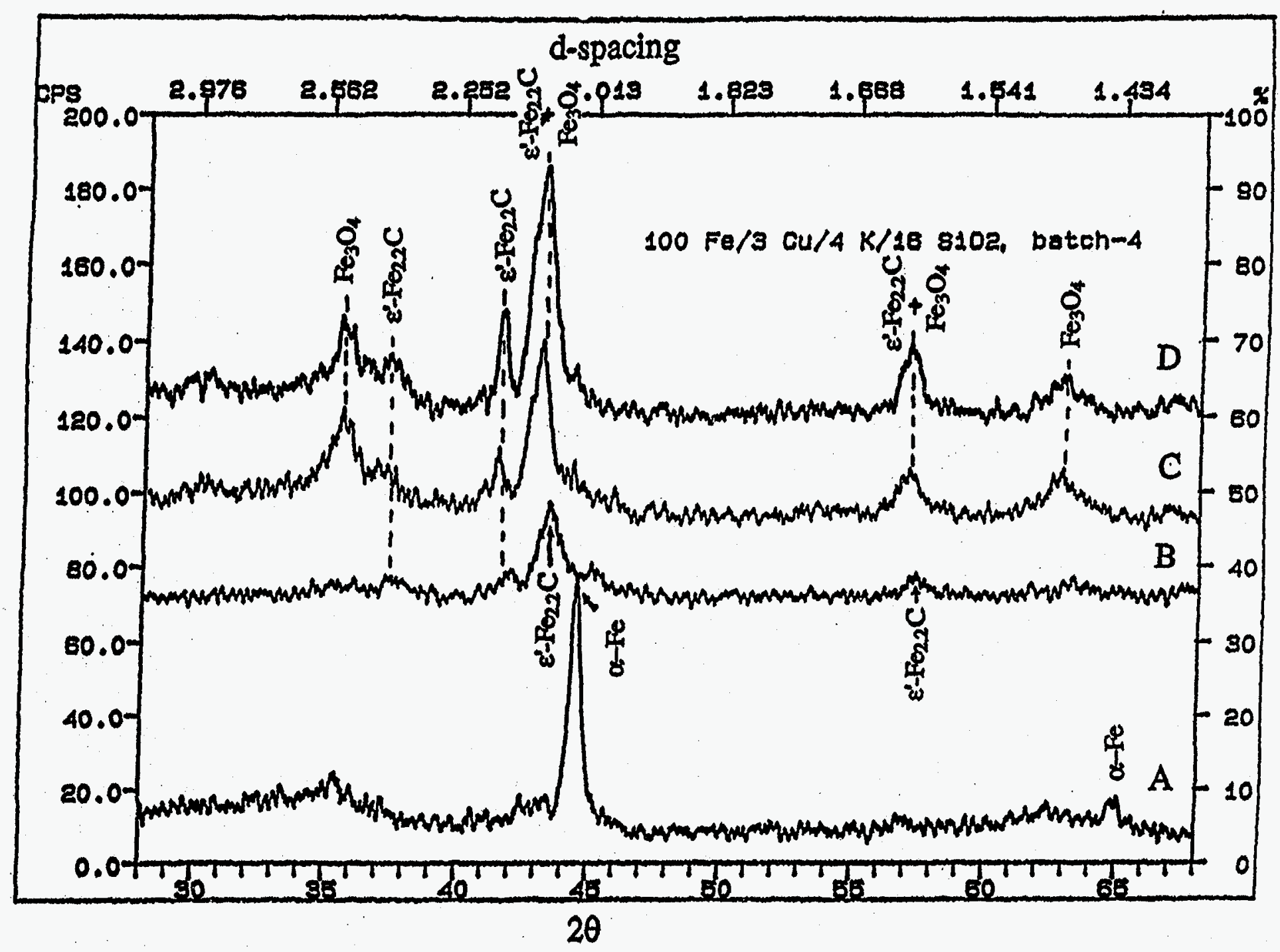

Figure 13. Change in bulk iron phases with time on stream during run SA-0376 with catalyst $\mathrm{C}\left(100 \mathrm{Fe} / 3 \mathrm{Cu} / 4 \mathrm{~K} / 16 \mathrm{SiO}{ }_{2}\right.$, batch 4): (A) TOS=0 h; (B) TOS=134 h; (C) TOS=230 h; and (D) TOS=350 h. 


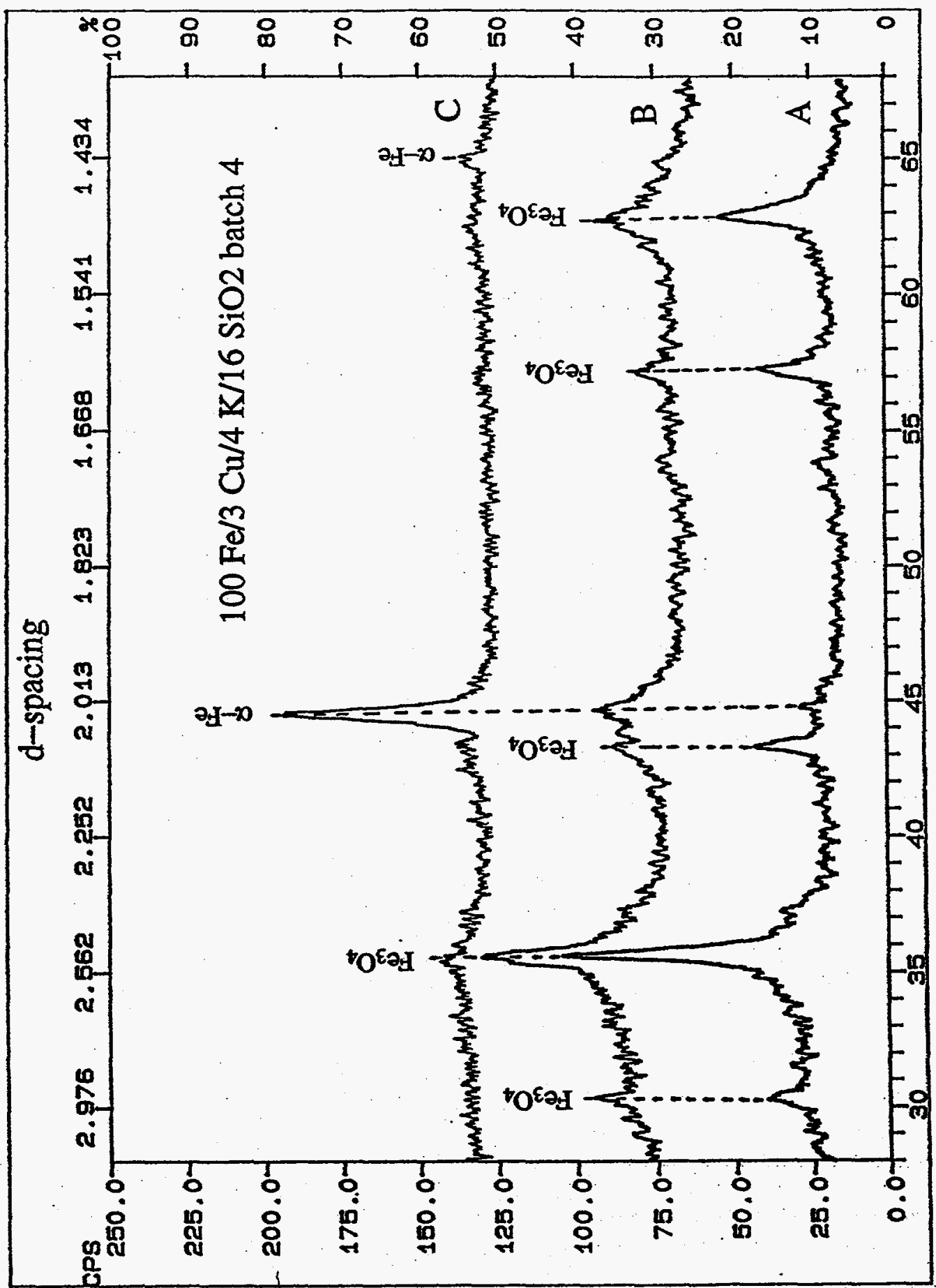

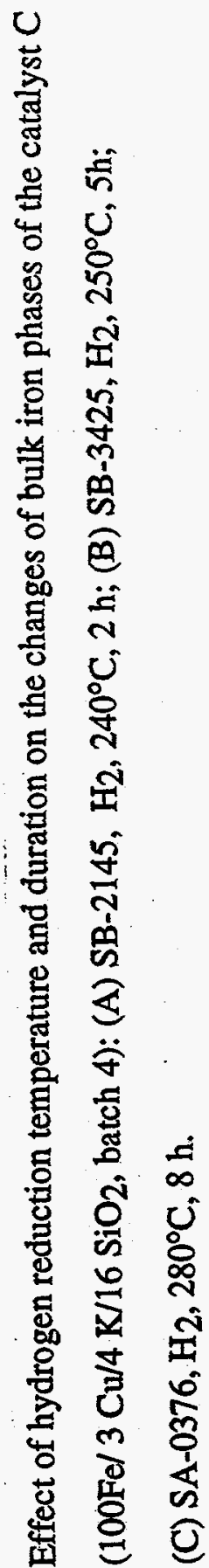




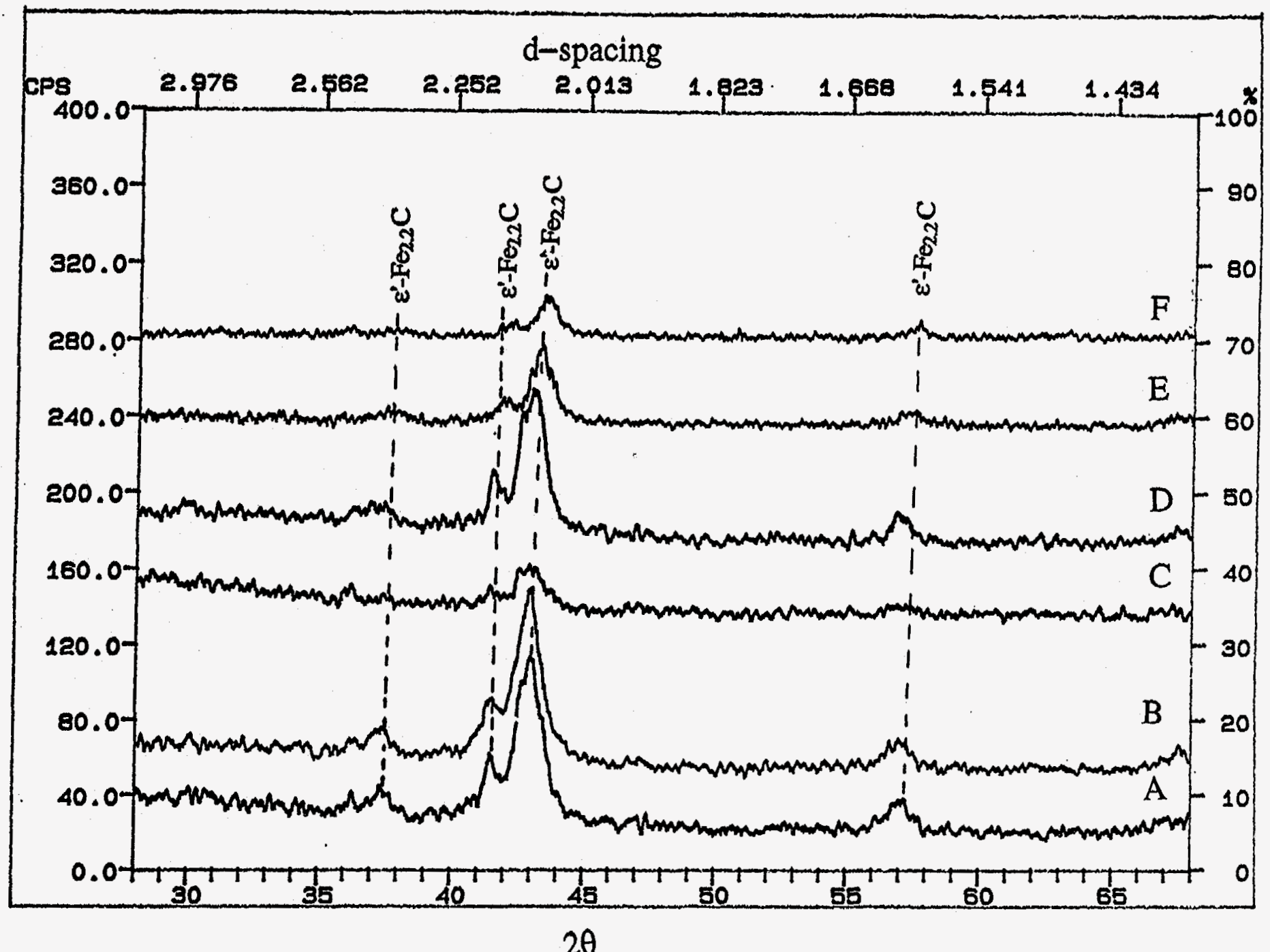

Figure 15. XRD patterns of the used catalysts from fixed bed reactor tests for calcination research: (A) FB-2975 (calcined at $400^{\circ} \mathrm{C}$ for $5 \mathrm{~h}$ ), top, TOS=142 h; (B) FB-2975, bottom; (C) FA-2925 (calcined at $500^{\circ} \mathrm{C}$ for $5 \mathrm{~h}$ ), top, TOS=140 h; (D) FA-2925, bottom; (E) FB-0236 (calcined at $700^{\circ} \mathrm{C}$ for $1 \mathrm{~h}$ ), top, TOS=120 h; (F) FB-0236, bottom. 


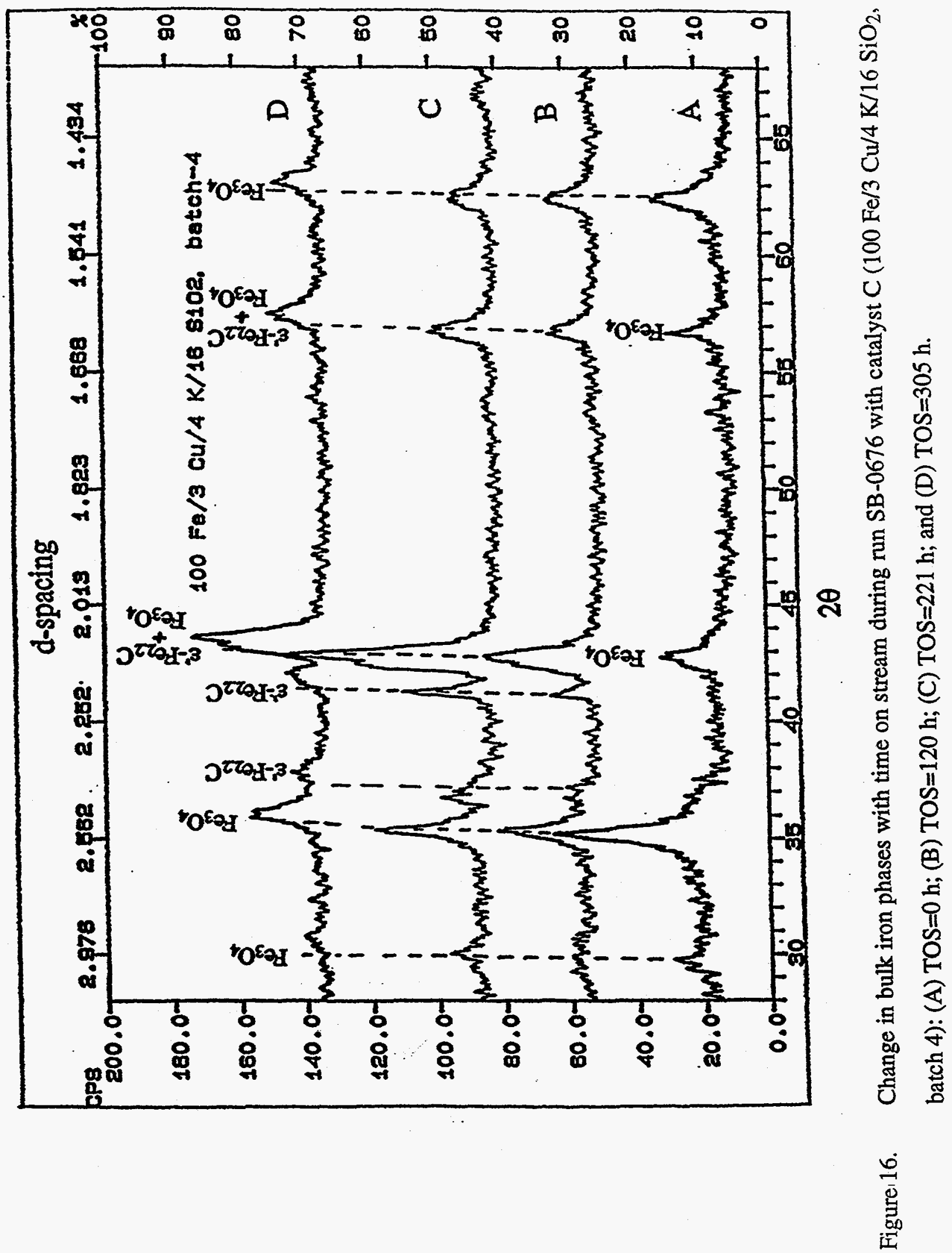




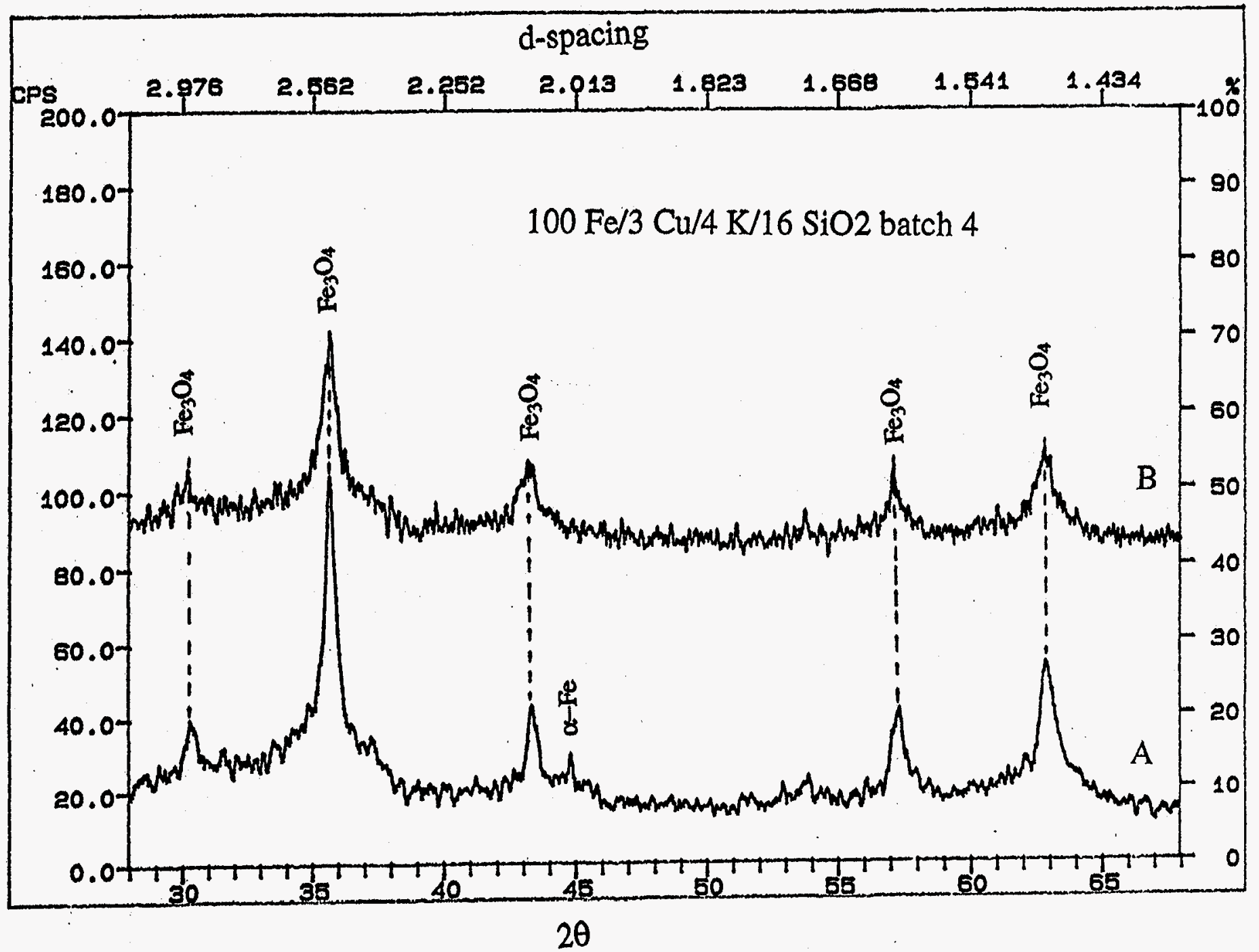

Figure 17. XRD patterns of catalyst samples withdrawn from slurry reactor tests for calcination research: (A) SB-2145 (calcined at $300^{\circ} \mathrm{C}$ for $5 \mathrm{~h}$ ), $\mathrm{H}_{2}, 240^{\circ} \mathrm{C}, 0.78 \mathrm{MPa}, 2 \mathrm{~h}, \mathrm{TOS}=0 \mathrm{~h}$; (B) SB-0676 (calcined at $700 \mathrm{C}$ for $1 \mathrm{~h}$ ), $\mathrm{H}_{2}$, $240^{\circ} \mathrm{C}, 0.78 \mathrm{MPa}, 2 \mathrm{~h}, \mathrm{TOS}=0 \mathrm{~h}$. 

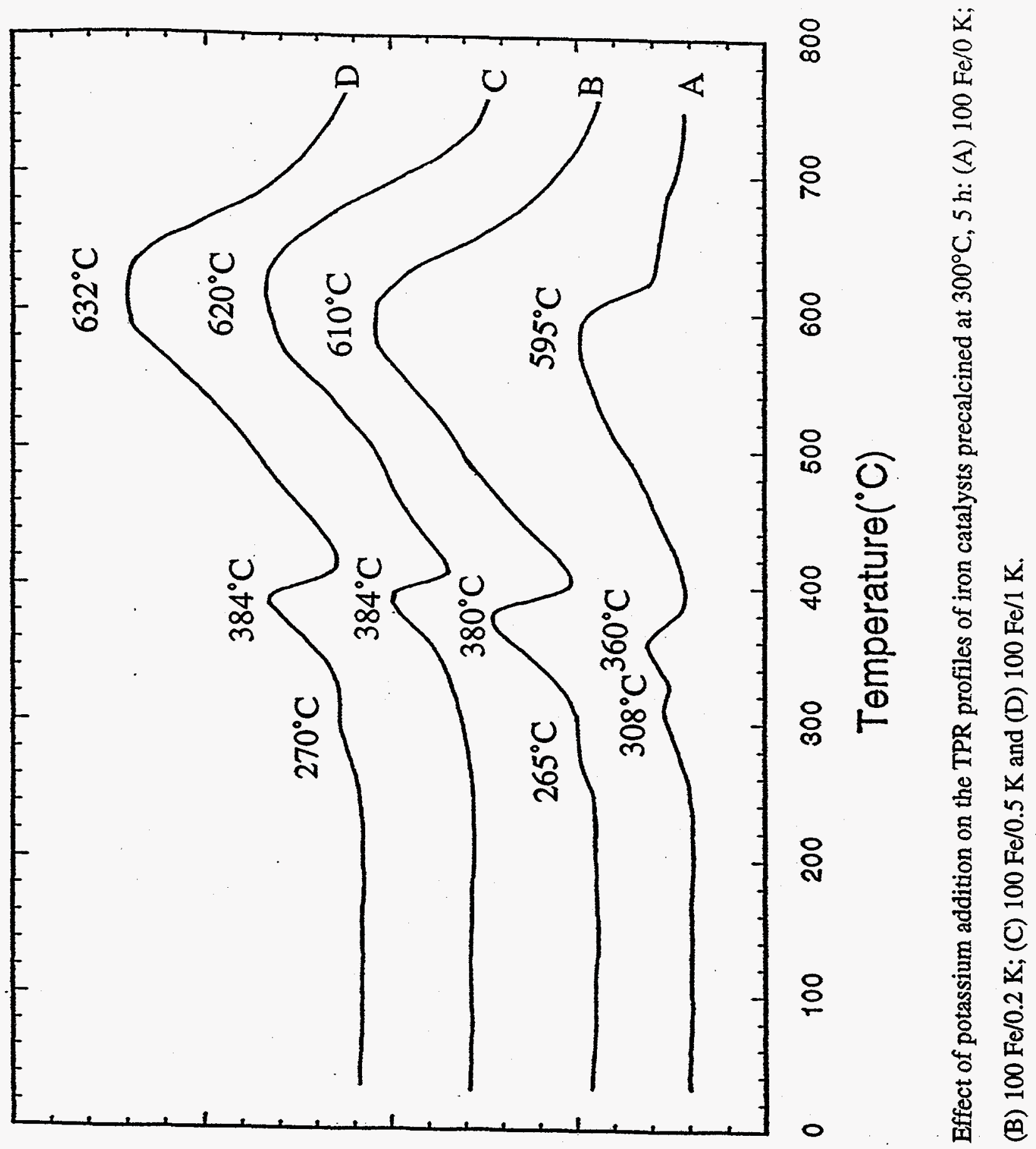

(qun Kreג!que)uoṇdunsuos ${ }^{2} \mathrm{H}$

$\underset{0}{\stackrel{\infty}{0}}$ 


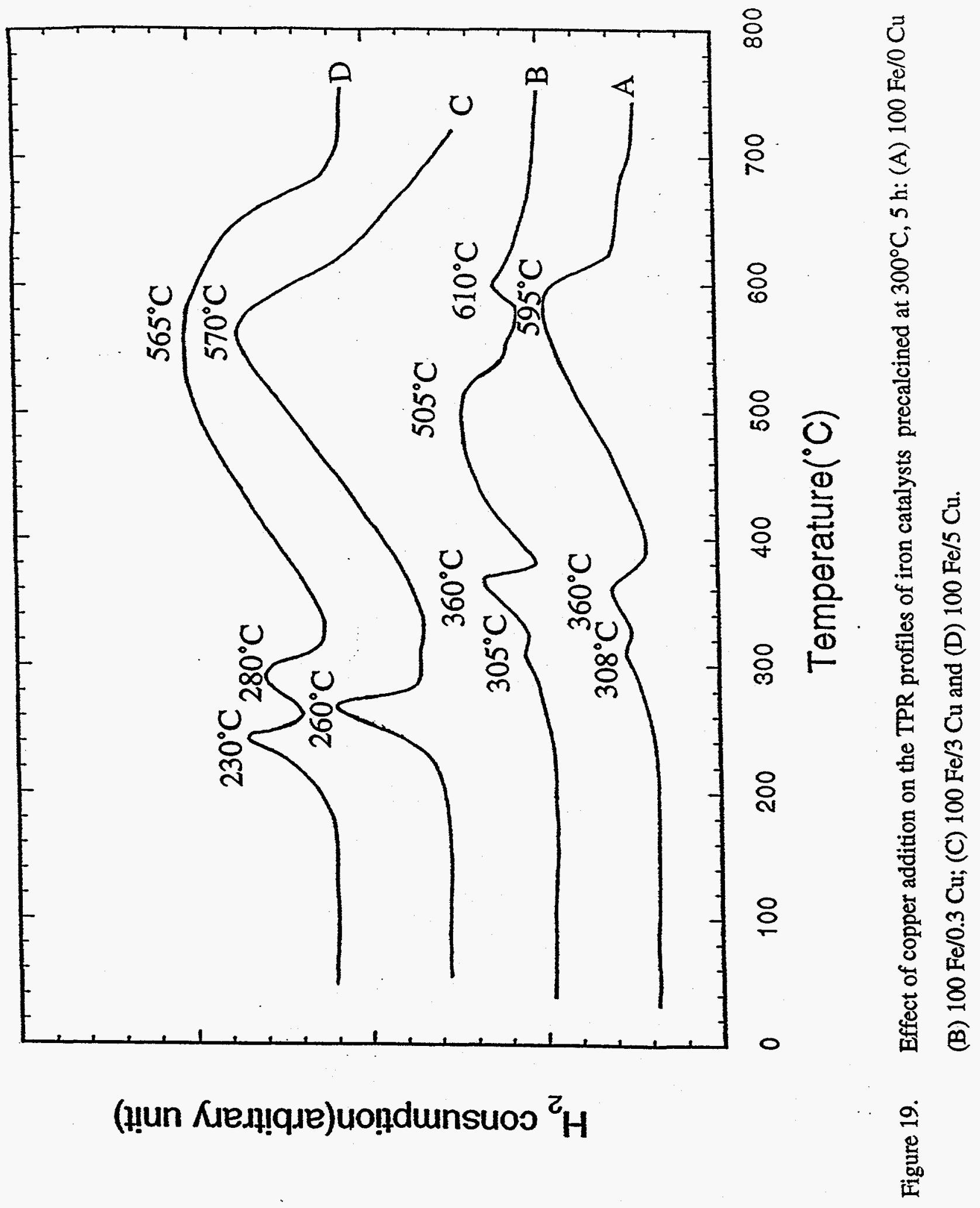




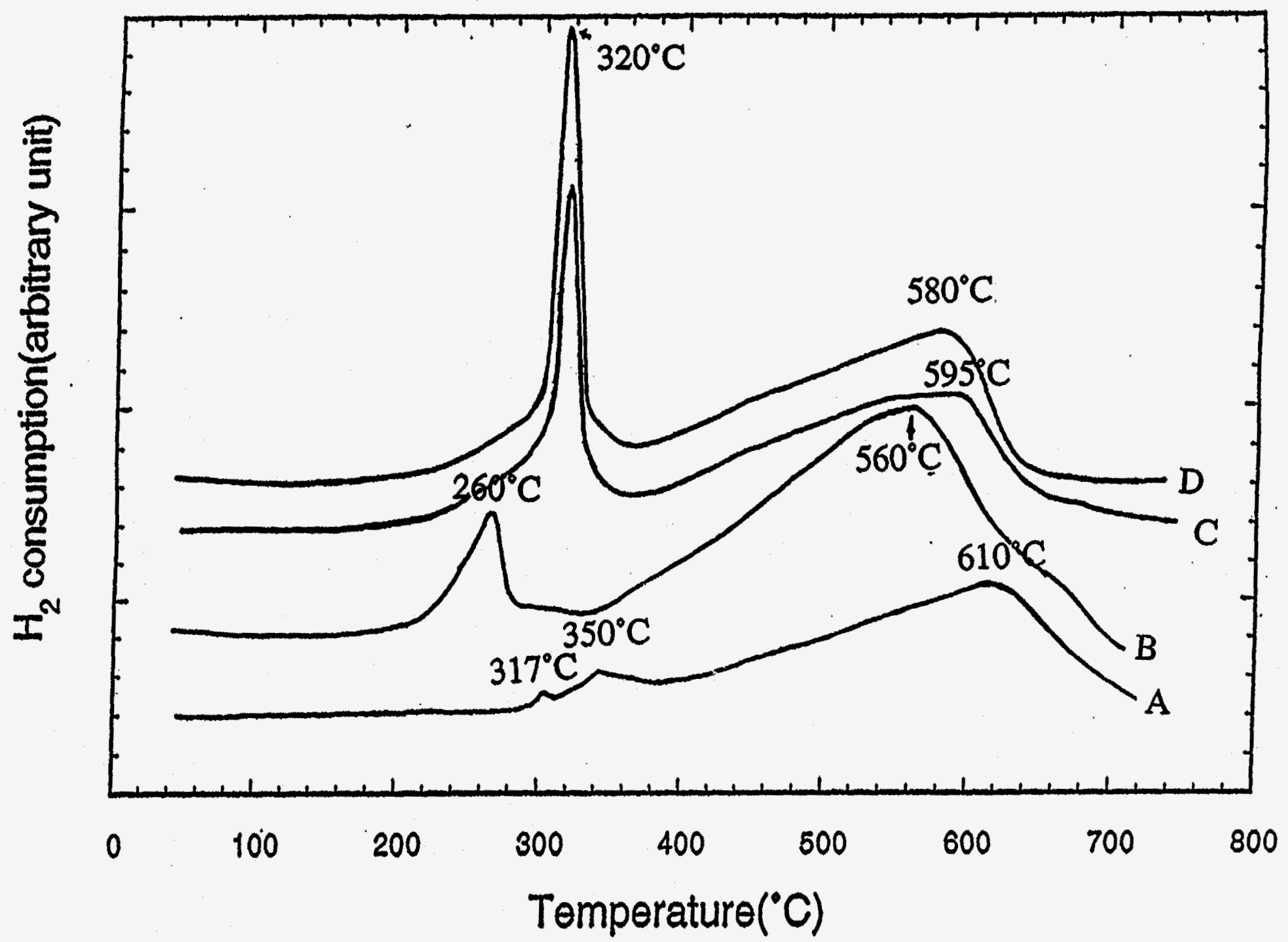

Figure 20. Effect of silica, potassium and calcium oxide addition on the TPR profiles of iron catalyst promoted with a fixed amount of copper at 3 parts. The catalysts are precalcined at $300^{\circ} \mathrm{C}, 5 \mathrm{~h}:(\mathrm{A}) 100 \mathrm{Fe} / 3 \mathrm{Cu} / 4 \mathrm{~K} / 6 \mathrm{Ca} / 16 \mathrm{SiO} 2$;

(B) $100 \mathrm{Fe} / 3 \mathrm{Cu}$; (C) $100 \mathrm{Fe} / 3 \mathrm{Cu} / 16 \mathrm{SiO}_{2}$ and (D) $100 \mathrm{Fe} / 3 \mathrm{Cu} / 4 \mathrm{~K} / 16 \mathrm{SiO}_{2}$. 


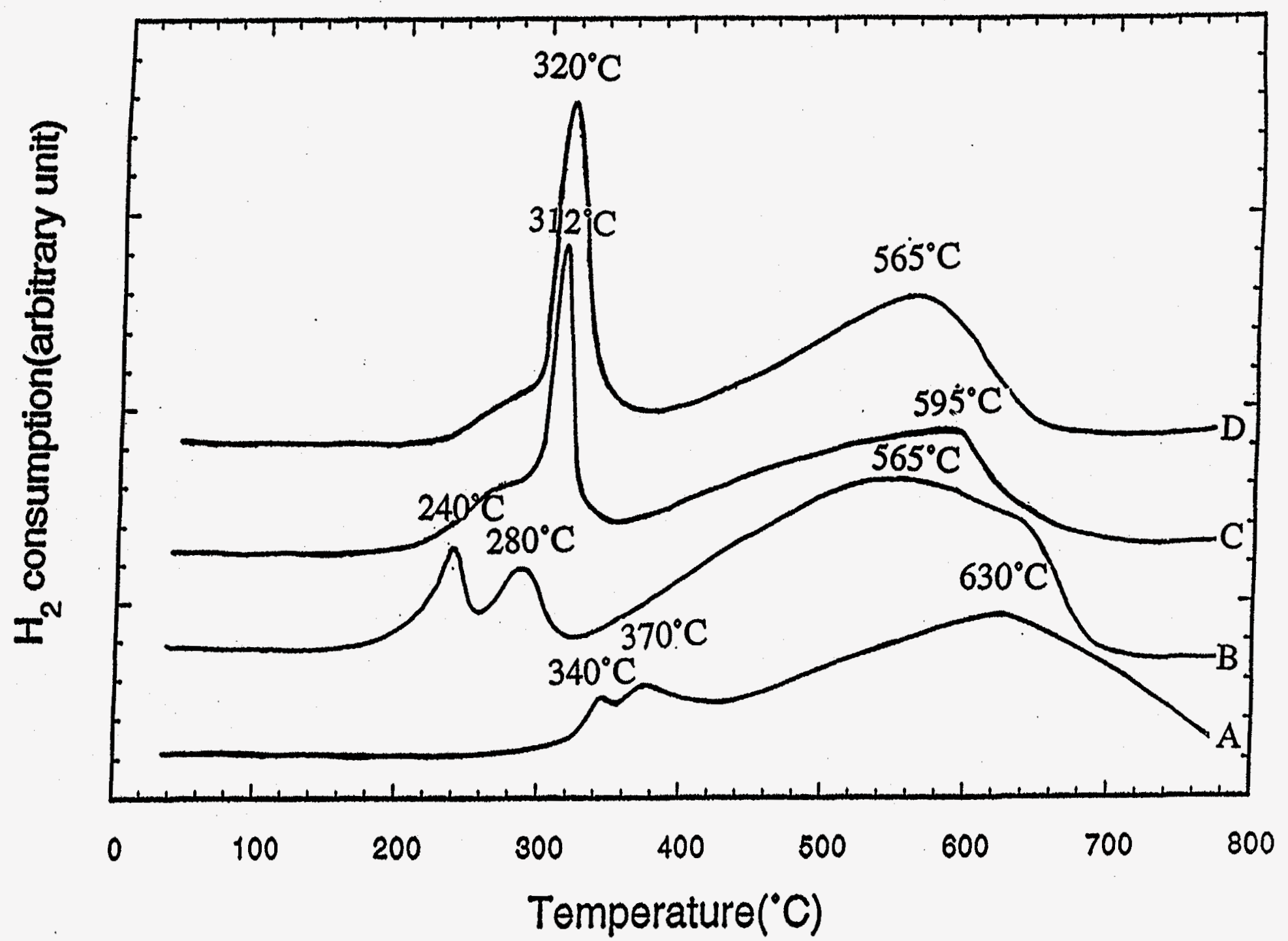

Figure 21. Effect of silica, potassium and calcium oxide addition on the TPR profiles of iron catalyst promoted with 5 parts of copper. All the catalysts are precalcined at $300^{\circ} \mathrm{C}, 5 \mathrm{~h}:$ (A) $100 \mathrm{Fe} / 5 \mathrm{Cu} / 6 \mathrm{~K} / 6 \mathrm{Ca} / 24 \mathrm{SiO}_{2}$; (B) $100 \mathrm{Fe} / 5 \mathrm{Cu}$; (C) $100 \mathrm{Fe} / 5 \mathrm{Cu} / 24 \mathrm{SiO}_{2}$ and (D) $100 \mathrm{Fe} / 5 \mathrm{Cu} / 6 \mathrm{~K} / 24 \mathrm{SiO}_{2}$. 


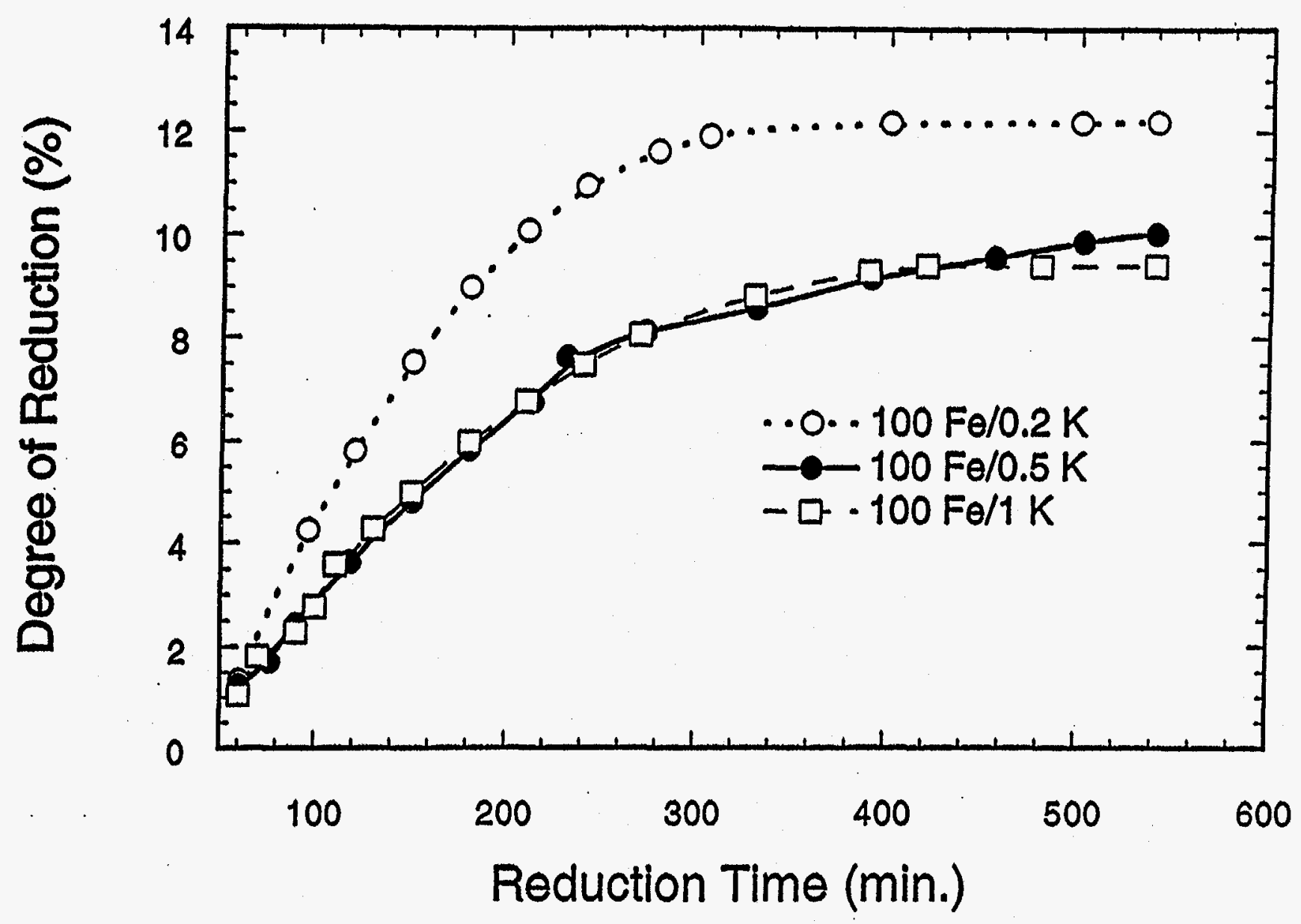

Figure 22. Effect of potassium addition on the degree of reduction of iron catalysts as a function of reduction time under isothermal conditions at $280^{\circ} \mathrm{C}$ in $5 \% \mathrm{H}_{2} / 95 \% \mathrm{~N}_{2}$ (determined using TPR apparatus, rate $=40 \mathrm{~m} 1 / \mathrm{min}$, ramp $=20^{\circ} \mathrm{C} /$ min until $280^{\circ} \mathrm{C}$ and maintained at this temperature for $8 \mathrm{~h}$ ). 


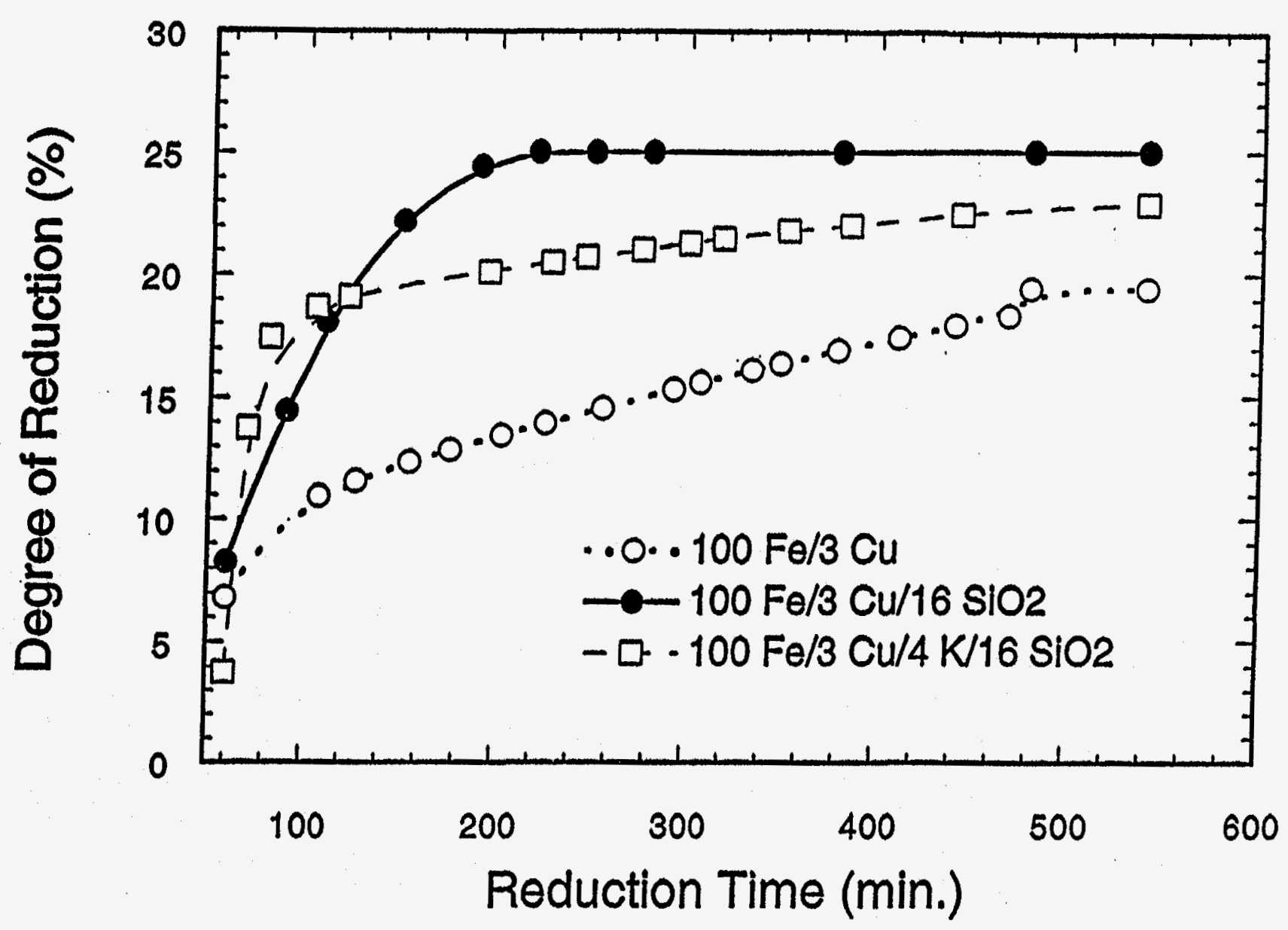

Figure 23. Effect of silica and potassium addition on the degree of reduction of iron catalyst promoted with 3 parts of copper as a function of reduction time under isothermal conditions at $280^{\circ} \mathrm{C}$ in $5 \% \mathrm{H}_{2} / 95 \% \mathrm{~N}_{2}$ (determined using TPR apparatus, rate $=40 \mathrm{ml} / \mathrm{min}$, ramp $=20^{\circ} \mathrm{C} / \mathrm{min}$ until $280^{\circ} \mathrm{C}$ and maintained at this temperature for $8 \mathrm{~h}$ ). 


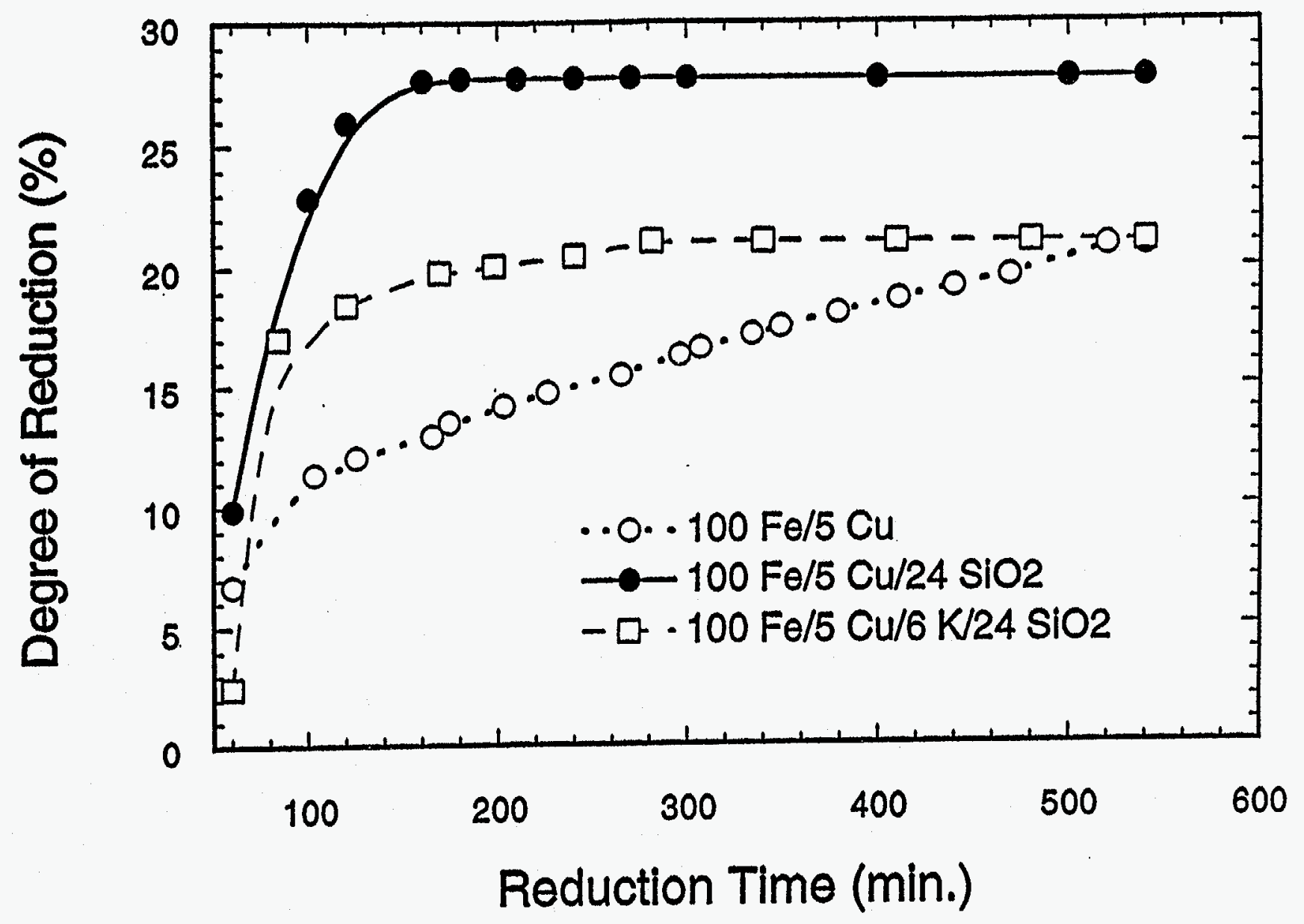

Figure 24. Effect of silica and potassium addition on the degree of reduction of iron catalyst promoted with 5 parts of copper as a function of reduction time under isothermal conditions at $280^{\circ} \mathrm{C}$ in $5 \% \mathrm{H}_{2} / 95 \% \mathrm{~N}_{2}$ (determined using TPR apparatus, rate $=40 \mathrm{ml} / \mathrm{min}, \mathrm{ramp}=20^{\circ} \mathrm{C} / \mathrm{min}$ until $280^{\circ} \mathrm{C}$ and maintained at this temperature for $8 \mathrm{~h}$ ). 


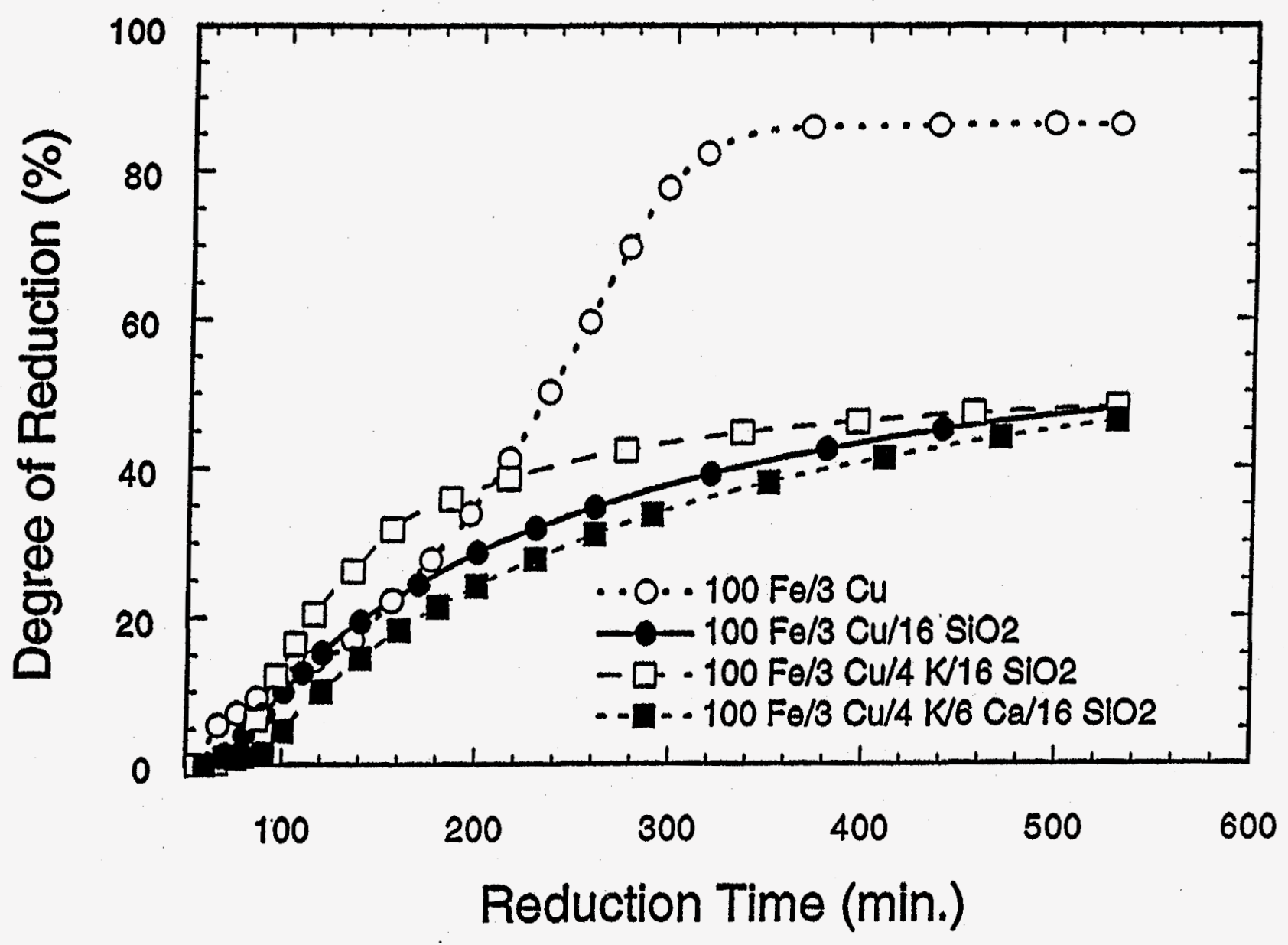

Figure 25. Effect of potassium, calcium, and silica addition on the degree of reduction of iron catalyst promoted with 3 parts of copper as a function of reduction time under isothermal conditions at $280^{\circ} \mathrm{C}$ in $\mathrm{H}_{2}$ (determined by TGA at a flow rate $=40 \mathrm{ml} / \mathrm{min}$, ramp $=5^{\circ} \mathrm{C} / \mathrm{min}$ until $280^{\circ} \mathrm{C}$ ). 


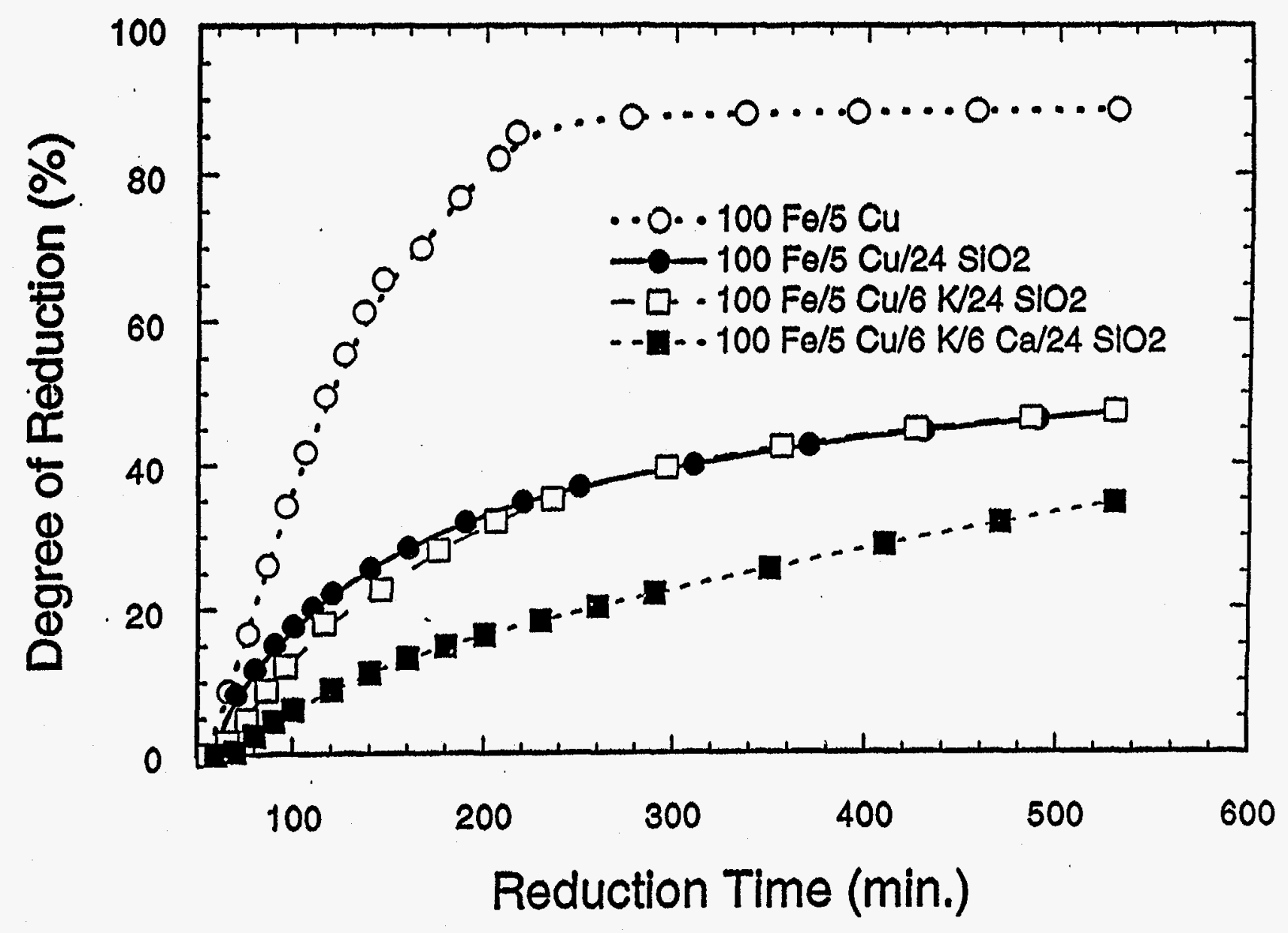

Figure 26. Effect of potassium, calcium, and silica addition on the degree of reduction iron catalyst promoted with 5 parts of copper as a function of reduction time under isothermal conditions at $280^{\circ} \mathrm{C}$ in $\mathrm{H}_{2}$ (determined by TGA at a flow rate $=40 \mathrm{ml} / \mathrm{min}, \mathrm{ramp}=5^{\circ} \mathrm{C} / \mathrm{min}$ until $280^{\circ} \mathrm{C}$ ). 
4 